\title{
Relativas cortadoras: mover e cortar? Ou cortar antes de mover?
}

\author{
Ana Espírito Santo
}

Centro de Linguística da Faculdade de Letras da Universidade de Lisboa

\begin{abstract}
:
With this article, we aim at providing an answer to two main theoretical questions: what is the syntactic derivation of European Portuguese P-chopping relative clauses? And what is the nature of the phonetically and semantically null element that integrates them? We also attempt to identify constants that allow us to predict other lexical contexts for the occurrence of P-chopping relative clauses other than the ones already described in the literature. We support our conclusions with the data collected in an acceptability judgment task that included 76 native speakers. Our proposal is a derivation for P-chopping relative clauses similar to the existing one for direct object relative clauses, assuming that the null element that integrates them has the properties of a variable.
\end{abstract}

Keywords: P-chopping relative clauses, raising analysis, DP movement, subcategorization properties of Vs

Palavras-chave: Relativas cortadoras, análise por elevação, movimento do DP, propriedades de seleção de Vs

\section{Introdução}

O presente trabalho propõe uma derivação das frases relativas cortadoras em português europeu (PE) semelhante à sugerida para as relativas de objeto direto (OD) por Brito (1991). Tanto as relativas de OD (cf. (1)) como as cortadoras (cf. (2)) são estruturas de relativização de objetos. No entanto, as relativas cortadoras resultam de uma estratégia não canónica de relativização de objetos preposicionados em que a preposição não é lexicalmente realizada:

(1) Este é o livroi que ${ }_{i}$ o Pedro comprou [Ø livro $]_{i}$.

(2) Esta é a rapariga $a_{i}$ que $_{i}$ o Miguel falou [da rapariga $]_{i}$.

Na presente proposta de derivação das relativas cortadoras, parte-se de uma análise de elevação das frases relativas que atualiza propostas anteriores de Kayne (1994) e Bianchi (1999) e incorpora igualmente contributos de Gallego (2003).

Na secção 2., descreve-se a estrutura das relativas cortadoras. A parte 3 sintetiza o que é dito na literatura sobre a atestação de frases relativas cortadoras na sincronia e na diacronia do português, referindo ainda os contextos mais propícios para a sua ocorrência em PE e as três análises que serviram de ponto de partida para este estudo. Na secção 4., damos conta dos objetivos que orientaram este trabalho. A parte 5. incide sobre as questões de investigação (QI). Na secção 6., descrevemos a tarefa experimental aplicada. Apresentamos depois os resultados do nosso estudo, articulando-os com as QI, na secção 7. Por fim, nas partes 8 e 9, discutimos os resultados obtidos e extraímos as principais conclusões.

\section{Estratégias de relativização}

Em PE, há três estratégias para a relativização de sintagmas preposicionais. A estratégia canónica é habitualmente designada como pied-piping (ou arrastamento de preposição). Neste caso, a preposição é "arrastada" em conjunto com o DP antecedente. No exemplo (3), observamos que a preposição é arrastada da sua posição argumental, adjacente ao verbo, para a posição inicial da frase relativa: 
(3) Esta é a rapariga de $_{\mathrm{i}}$ quem $_{\mathrm{i}}$ o Pedro gosta [da rapariga $]_{\mathrm{i}}$.

Os falantes de PE relativizam objetos oblíquos recorrendo ainda a duas estratégias não-canónicas, a ressuntiva e a cortadora. Na primeira, a análise tradicional assume que a preposição não se move, sendo inserido, na frase relativa, um elemento ressuntivo que retoma os traços de género e número do antecedente. As frases relativas ressuntivas são introduzidas pelo relativizador (não pelo pronome relativo) que:

(4) Esta é a rapariga que $_{\mathrm{i}}$ o Pedro gosta dela

$\mathrm{Na}$ segunda, os falantes relativizam sintagmas preposicionais recorrendo à estratégia cortadora (também referida como $P$-chopping ${ }^{l}$ ). De acordo com a literatura, o relativizador preferencial nas frases relativas cortadoras é o morfema que, independentemente da função sintática do objeto relativizado (Peres e Móia, 1995:276; Alexandre e Hagemeijer, 2013:7). Nesta estratégia, a preposição selecionada pelo verbo da frase relativa não tem realização lexical e fonética, como se exemplifica em (5):

\section{(5) Esta é a rapariga que $_{i}$ o Pedro gosta [da rapariga $]_{i}$.}

O presente trabalho foca-se na estratégia cortadora. Para compreender qual a derivação sintática que melhor a descreve, partimos de uma questão de base: o facto de a estratégia cortadora ocorrer mais frequentemente com um conjunto restrito de combinações de verbo e preposição (nomeadamente, gostar de, falar de, necessitar de, precisar de e chamar a) deve-se a alterações nas propriedades de seleção destes verbos? Para este efeito, desenvolvemos uma tarefa experimental em que testámos estes e outros verbos em frases declarativas simples que não incluem relativas. Com esta tarefa, procurámos ainda clarificar a natureza do elemento que introduz as frases relativas cortadoras (pronome relativo ou complementador) e a relação entre o recurso a esta estratégia e a frequência absoluta destas combinações de verbo e preposição. Considerámos igualmente a possibilidade de esta estratégia ocorrer devido à perda de peso semântico ou fonológico das preposições.

Por último, importa acrescentar que este estudo foi levado a cabo junto de um público homogéneo, instruído e sujeito a ensino formal (o juízo de aceitabilidade foi aplicado a estudantes universitários). Desta forma, não foram manipulados fatores extralinguísticos (tais como a formalidade do discurso ou o nível de instrução) que podem potenciar a produção de frases relativas com a estratégia canónica, como sugere Kenedy (2007) para o português do Brasil. Kenedy (2007) defende que a relativização com pied-piping é "antinatural”, resultando de instrução explícita e de ensino formal, ao passo que as relativas cortadoras são uma estrutura sintática mais natural. O estudo da interferência destas variáveis em português europeu foi levado a cabo por Santos (2014), que, em termos gerais, concluiu que o fator escolaridade é o principal influente na concretização da estrutura com pied-piping (Santos, 2014:46), sendo a estratégia cortadora a mais frequentemente produzida na fala espontânea dos falantes nativos de PE, independentemente do nível de escolaridade.

\section{Estado da arte}

As relativas cortadoras são uma estratégia atestada na diacronia do PE. Duarte (2013) chama a atenção para a ocorrência de frases relativas cortadoras nos Cancioneiros da Ajuda e d'el-rey D. Dinis:

\footnotetext{
${ }^{1}$ A regra de transformação "cortadora" foi primeiramente referida por Ross (1967) (apud Alexandre, 2012:84). Tarallo (1985) designou como "cortadoras" as frases que envolvem esta estratégia, assumindo que a preposição está inicialmente presente e é depois cortada. Klein (1993) prefere designar estas estruturas como "relativas de preposição nula" ('null-preposition'), argumentando que há uma preposição que não é lexicalmente realizada, presente na estrutura da frase. Neste estudo, adotaremos a designação "relativas cortadoras", uma vez que é a mais comummente utilizada na literatura sobre o tema para o português europeu.
} 
(6) o dia Ø que eu tal pesar vi [emo-dia]

(Cancioneiro da Ajuda, 10224; apud Huber 1933, apud Duarte 2013:8)

(7) De aquel tempo Ø que eu vos vi e oí passar [em aquel tempe]

(Canc. d'el-rey D. Denis, 880; apud Huber 1933, apud Duarte 2013:8)

Sincronicamente, esta estratégia está presente noutras variedades do português, tais como o português de São Tomé (cf. (8), o português de Cabo Verde (cf. (9)) (Gonçalves, 2010; Alexandre, Gonçalves e Hagemeijer, 2011) e o português do Brasil (cf. (10)) (Tarallo, 1985; Kato e Nunes, 2009, entre outros):

Português de S. Tomé

(8) Tenho uma moça lá em casa Ø que não chamo empregada [a uma moça].

Português de Cabo Verde

(9) Faz umas coisas Ø que eu não gosto [de umas coisas].

(ambas de Alexandre, Gonçalves e Hagemeijer, 2011:22)

Português do Brasil

(10) Nova Iorque é uma cidade Ø que você respira Gershwin [em Nova Iorque]

(Tarallo, 1985:358)

Há ainda evidência do recurso à estratégia cortadora noutras línguas, tais como o crioulo do Haiti, certos dialetos do grego, o espanhol de Porto Rico coloquial, o italiano coloquial, o espanhol da Venezuela, o catalão, o francês de Montreal e Quebeque, o francês antigo (XVII) e o roviana (falado nas ilhas Salomão) (Klein, 1993). Abaixo apresenta-se um exemplo do roviana, mostrando que a preposição selecionada na frase declarativa (11a.) está ausente na frase relativa (11b.), e um exemplo de uma relativa cortadora no espanhol da Venezuela (cf. (12)):

$\begin{array}{llllllll}\text { (11) a. Ele ponia Jone } & \text { koe } & \text { Mere } & \text { sa } & \text { buka. } & \\ \text { PST dar } \quad \text { João } & \text { Prep } & \text { Maria } & \text { DET } & \text { livro } & \\ \text { 'O João deu o livro à Maria.' } & & & & & \\ \text { b. Sa } & \text { barikalege } & \text { sapu } & \text { ele } & \text { ponia } & \text { buka } & \text { Jone. } \\ \text { DET } & \text { mulher } & \text { que } & \text { PST } & \text { dar } & \text { livro } & \text { João }\end{array}$

'A mulher Ø que o João deu o livro.'

(Exemplos de Klein, 1993:128)

(12) Puse mucho énfasis en las secciones $\varnothing$ que se discuten los aspectos gramaticales [en-estas secciones]

'Coloquei muita ênfase nas secções Ø que se discutem os aspetos gramaticais'

(Exemplo do espanhol da Venezuela de Flores, 1987:2, apud Klein, 1993:191) 


\subsection{Contextos de ocorrência}

Os estudos não são consensuais quanto à relevância da estratégia cortadora entre os falantes nativos do PE. Alguns autores consideram-na uma opção em crescimento, mas menos comum do que a estratégia ressuntiva $^{2}$ (Peres e Móia, 1995); outros afirmam que a estratégia cortadora é mais produtiva do que a ressuntiva, mas menos frequente do que o recurso ao pied-piping (Alexandre, 2000; Arim, Ramilo e Freitas, 2004). Há ainda investigadores que identificam uma mudança em curso na língua, destacando o facto de a estratégia cortadora integrar o discurso oral de falantes altamente escolarizados (Brito e Duarte, 2003a:667; Santos, 2014; Aßmann e Rinke, 2017³).

No que diz respeito aos contextos de ocorrência, alguns autores focaram-se na função sintática do objeto relativizado (e.g. Veloso, 2013; Aßmann e Rinke, 2017), ao passo que outros preferiram uma abordagem lexical, salientando os verbos e/ou preposições normalmente associados às frases cortadoras (e.g. Arim, Ramilo e Freitas, 2004), destacando, em concreto, as combinações gostar de, falar de, precisar de, necessitar de e chamar $a$.

Os autores que seguem a abordagem sintática não concordam quanto aos contextos em que esta estratégia é mais frequente. Por exemplo, Veloso (2013) afirma que a estratégia cortadora é mais frequente quando são relativizados PPs com valor temporal ou locativo, seguindo-se os verbos que selecionam a preposição funcional de/a (como falar, gostar ou precisar). Aßmann e Rinke (2017:31) identificaram os casos em que o objeto indireto é relativizado como os mais propensos à ocorrência de relativas cortadoras $(97,4 \%$ do total de objetos indiretos), sendo depois seguidos de complementos verbais (93,1\% do total de complementos verbais) e só depois de PPs com valor temporal (76,8\% do total de PPs com valor temporal), locativo (58,6\% do total de PPs com valor locativo) ou oblíquo (51,5\% do total de PPs com valor oblíquo) ${ }^{4}$. Já Santos (2014) destaca os complementos nominais e os adjuntos verbais, bem como as preposições de, a, com e em.

Em suma, apesar das divergências, os investigadores estão de acordo quanto ao facto de as combinações gostar de, falar de, precisar de e necessitar de serem as mais propícias à ocorrência de frases relativas cortadoras. A estas, Arim et al. (2004) acrescem chamar a.

\subsection{Análises existentes}

Várias são as propostas para a estrutura das frases relativas cortadoras. Tarallo (1985: 371) sugere que a estratégia cortadora resulta de um processo de elipse numa estrutura ressuntiva, tendo em conta a possibilidade de ocorrência de objeto nulo em PB. Assume, assim, um pronome ressuntivo no início da derivação, que é elidido (objeto nulo). A preposição é posteriormente apagada.

Klein (1993) rejeita esta relação entre a ocorrência de frases relativas cortadoras e a possibilidade de elipse do objeto em frases matriz. Na análise de Klein (1993), há um PP vazio, gerado na base, que legitima um pro como objeto. O NP nulo é selecionado pela preposição nula e depois cliticiza na preposição por razões fonológicas, criando um novo objeto nulo. Uma vez que a preposição também é nula, o resultado é um PP sem realização lexical.

\footnotetext{
2 “(...) mas é indubitável que a primeira [ressuntiva] é muito frequente e generalizada no discurso oral e a segunda [cortadora] está progressivamente a ganhar terreno, possivelmente por influência do português do Brasil.” (Peres e Móia, 1995: 291).

${ }^{3}$ Santos (2014) analisou a produção de relativas cortadoras numa perspetiva sociolinguística, concluindo que a estratégia cortadora é a estratégia de relativização de sintagmas preposicionais mais frequente no corpus da fala bracarense, independentemente do grau de escolarização dos falantes. Aßmann e Rinke (2017) realizaram também um estudo de corpora, considerando o corpus analisado por Santos (2014), mas incluindo igualmente dados do Corpus Dialectal para o Estudo da Sintaxe, CORDIAL-SIN. Nos dados analisados por estas autoras, de um total de 189 frases relativas preposicionadas, 145 (76,7\%) envolveram a não realização lexical da preposição e 44 (23,3\%) apresentaram a preposição realizada lexicalmente (cf. Aßmann e Rinke 2017:31, tabela 6).

${ }^{4}$ A distinção entre complementos verbais e oblíquos aqui referida é a estabelecida pelas autoras no artigo, não nos sendo absolutamente claro a que se refere esta diferença. As percentagens aqui reproduzidas são as apresentadas pelas autoras no artigo.
} 
Brito (1995) segue uma abordagem diferente. Começa por rejeitar a relação entre relativas cortadoras e alterações nas propriedades de seleção categorial dos verbos, pois “(...) o mesmo tipo de falantes que produz relativas como as indicadas [cortadoras] respeita os requisitos de seleção categorial e temática noutros tipos de frases" (Brito, 1995:76). Assim, de acordo com esta autora, o elemento que introduz as relativas cortadoras é um "marcador geral de subordinação", com características mais próximas de um complementador (COMP) e não tanto de um pronome relativo. A categoria vazia no interior da frase relativa tem propriedades de variável e é interpretada correferencialmente em relação ao antecedente, com a intervenção de um operador relativo nulo junto do COMP (sendo o movimento de operador semelhante ao das relativas de SU e OD). O COMP é gerado na base e a regra de predicação assegura a coindexação entre o antecedente e a categoria vazia (Brito, 1995:7677).

\subsection{Ponto de partida}

Como ponto de partida, equacionámos três possíveis derivações para as frases relativas cortadoras, partindo de uma análise por elevação (seguindo a proposta de Bianchi, 1999, que atualiza Kayne, 1994).

A primeira possibilidade é admitir que as frases relativas cortadoras mantêm a estrutura das frases relativas preposicionadas com pied-piping. Isto significa que as relativas cortadoras são geradas com movimento do PP relativizado, sendo a preposição apagada na interface. A aceitação de frases relativas cortadoras introduzidas por pronome relativo (tais como '*este é o rapaz quem a Maria gosta') seria um dado empírico a favor desta estrutura. Para testar esta hipótese, como veremos mais adiante, recorremos ao pronome relativo quem, pois a forma que é ambígua entre um pronome relativo (por exemplo, na frase este é o livro de que a Maria gosta) ou um complementador (por exemplo, na frase este é o bolo que o João comeu). Quem só ocorre em estruturas em que há movimento do PP, i.e., com pied-piping da preposição. Caso os dados apontem para uma análise com movimento do PP relativizado, será necessário compreender as razões que motivam a queda da preposição na sua posição canónica.

Uma segunda hipótese é considerar que as frases relativas cortadoras contêm uma cadeia sem movimento, semelhante à proposta feita para as relativas ressuntivas (Alexandre, 2000). Neste caso, na numeração, estão presentes uma preposição e um pro (seguindo Klein, 1993) ou um pronome ressuntivo nulo (na esteira de Tarallo, 1985). Tal como nas ressuntivas, o DP antecedente é inserido por merge em Spec, CP, e o pronome ressuntivo/pro ocupa a posição argumental, como complemento da preposição que é o núcleo da projeção PP. A não realização lexical do PP pode ocorrer por razões fonológicas, se considerarmos que a preposição é nula e que o NP é um pro, na linha de Klein (1993). Por outro lado, pode adotar-se uma versão atualizada da proposta de Tarallo (1985), uma vez que não é necessário assumir que a queda da preposição depende da queda do objeto, pois, no quadro minimalista atual, estas podem ocorrer em simultâneo. Uma hipótese deste tipo (i.e., uma cadeia sem movimento) será excluída se encontrarmos evidências do movimento do DP antecedente.

Por último, na linha de Brito (1995), podemos assumir que as frases relativas cortadoras têm uma derivação equivalente à proposta para as relativas de sujeito e de objeto direto. Isto é, há um complementador que, gerado no núcleo de $\mathrm{C}^{\mathrm{o}}$, que sonda um elemento com um traço [DET] (e não [Prep]). Consequentemente, o DP antecedente move-se, mas a preposição que c-comanda o constituinte relativizado permanece in situ. Uma vez que, em PE, não há abandono de preposição (ao contrário do inglês), esta é apagada na componente fonológica. A favor desta análise, estarão dados que comprovem o movimento do DP antecedente e a natureza de complementador do elemento de relativização.

\section{Objetivos de investigação}

Três objetivos motivaram este estudo. Considerando a relativização de PPs que são complementos do V, em primeiro lugar, procurámos saber qual a derivação sintática mais adequada para as relativas cortadoras em 
PE. Em segundo lugar, tentámos identificar a natureza do elemento nulo (variável ou pro) e a sua categoria sintática (DP ou PP), através de pistas que nos ajudassem a diagnosticar o movimento da preposição (não realizada lexical e foneticamente). Por último, tentámos averiguar se há algum fator que propicie a ocorrência de relativas cortadoras, tal como a frequência absoluta das combinatórias $\mathrm{V}+$ Prep em que esta é mais frequente, ou a escassa robustez acústica e/ou semântica da(s) preposição(ões) mais propensas à omissão. Se identificarmos este(s) fator(es), poderemos predizer novos contextos lexicais para o corte da preposição em frases relativas.

\section{Questões de investigação}

Para desenvolver uma proposta para a sua derivação sintática, guiámo-nos pela seguinte questão de investigação:

QI1: Os verbos que ocorrem em relativas cortadoras mostram variação no que diz respeito à categoria do complemento que selecionam?

Se a resposta for negativa, i.e., se os verbos mantiverem as suas propriedades de seleção nas frases relativas cortadoras (na linha de Brito, 1995), a predição é que os falantes não aceitem a queda da preposição noutras estruturas, como as frases declarativas, e que considerem frases como as exemplificadas em (13) e (14) agramaticais:

(13) *O Vasco gosta livros.

(14) *O Francisco precisa uma mochila.

No entanto, se as propriedades de seleção destes verbos estiverem em processo de mudança, esperamos que os falantes mostrem variação na aceitabilidade da queda de preposição em frases declarativas e que, para alguns falantes, as mesmas frases, agora exemplificadas em (15) e (16), sejam gramaticais:

(15) O Vasco gosta livros.

(16) O Francisco precisa uma mochila.

Caso não se verifiquem alterações nas propriedades de seleção dos verbos, o diagnóstico do movimento do DP pode ser feito com recurso aos testes habitualmente utilizados para este efeito, nomeadamente, cruzamento forte, lacunas parasitas e ilhas fortes.

Ao levar a cabo estes testes, verificamos que a cópia nula é sensível a efeitos de cruzamento forte (cf. (17)), legitima lacunas parasitas (cf. (18)) e é sensível a movimento longo, i.e., a ilhas fortes (cf. (19) - (21)):

\section{Cruzamento forte}

(17) *Aqui está a rapariga que a Joana $_{\mathrm{i}}$ gosta $t_{\mathrm{i}}$

\section{Lacunas parasitas}

(18) Este é o autor que $_{\mathrm{i}}$ eu gosto $t_{\mathrm{i}}$ apesar de nunca ter lido $\mathbf{e}_{\mathrm{i}}$

\section{Ilhas fortes}

[Nominativa, (17a.) e (17b.)] 
(19) a. *Os livrosi [que falar $t_{\mathrm{i}}$ se tornou difícil] estão aqui.

b. ${ }^{*} \mathrm{O}$ modo $_{\mathrm{i}}$ [que $_{\mathrm{i}}$ comportar-se $t_{\mathrm{i}}$ seria inadequado] é o seguinte.

[NP Complexo, (18a.) e (18b.)]

(20) a. *A pessoa ${ }_{i}\left[q^{2} e_{i}\right.$ tu encontraste alguém que falaria $\left.t_{\mathrm{i}}\right]$ está doente

b. ${ }^{*} \mathrm{O} \operatorname{modo}_{\mathrm{i}}\left[\right.$ que $_{\mathrm{i}}$ tu encontraste alguém que arranjaria o carro $t_{\mathrm{i}}$ ] agrada-me.

[Adjunto, (19a.) e (19b.)]

(21) a. *A pessoa ${ }_{\mathrm{i}}\left[\mathrm{que}_{\mathrm{i}}\right.$ tu partiste sem falares $\left.t_{\mathrm{i}}\right]$ adoeceu.

b. *O modo [que $_{\mathrm{i}}$ ele foi despedido [depois de se ter comportado $t_{\mathrm{i}}$ ]] foi indecente.

Para identificar a natureza do elemento nulo e a categoria sintática a que pertence, procurámos compreender se os dados empíricos confirmam ou infirmam o que é dito na literatura em relação ao elemento que introduz as cortadoras. Propusemo-nos responder à segunda questão de investigação:

\section{Q12: As cortadoras são introduzidas por um pronome relativo ou por um complementador?}

Havendo dados empíricos a suportar a ideia de que o elemento que introduz as cortadoras é um complementador, este é um argumento para defender o movimento do DP (e não do PP). O contrário suporta o movimento do PP.

Os pronomes relativos distinguem-se dos complementadores quanto à sensibilidade a traços de animacidade (visíveis nos pronomes relativos, mas não nos complementadores) ${ }^{5}$, à presença/ausência de marcas de flexão em número e caso (presentes nos pronomes relativos e não nos complementadores) e à possibilidade de serem selecionados por preposição (os pronomes relativos podem ser selecionados por uma preposição, ao passo que os complementadores não ${ }^{6}$ ( (cf. Brito, 1991; Rinke e Aßmann, 2017, entre outros).

Em PE, diferenciam-se o complementador que, elemento introdutor das frases relativas de sujeito e de objeto direto, dos pronomes relativos invariáveis quem, onde e que (em frases relativas preposicionadas) e dos pronomes relativos variáveis $o(a)(s)$ qual(is), quanto(a)(s) e cujo(a)(s) (Brito, 1991).

Assim, se as frases relativas cortadoras forem introduzidas por um pronome relativo, a predição é que os falantes aceitem estruturas relativas cortadoras introduzidas pelos pronomes relativos quem ou o qual, tais como as apresentadas em (22) e $(23)^{7}$ :

\footnotetext{
${ }^{5}$ Em particular, neste estudo, o traço [+humano] foi o considerado para contrastar os contextos de ocorrência do pronome relativo e do complementador, nomeadamente através do uso do pronome relativo quem. Considerando o conjunto das entidades que denotam o traço [+animado], quem ocorre preferencialmente com o subconjunto das entidades que denotam os traços [+animado, +humano] (cf. i), não sendo tão natural com entidades com os traços [+animado, - humano] (cf. ii):

(i) Esta é a rapariga de quem ele gosta.

(ii) ? Este é o cão de quem ele gosta.

${ }^{6}$ Rinke e Aßmann (2017) defendem que estes critérios nem sempre são válidos. As autoras apresentam exemplos de complementadores que têm marcas de flexão e de pronomes relativos que não flexionam em todos os casos. Para além disso, as autoras pensam que alguns complementadores podem ser sensíveis à animacidade do antecedente.

${ }^{7}$ Um revisor anónimo sugeriu que sequências como "?O rapaz que gosto é simpático", com antecedente humano e o relativizador que, deveriam ser testadas. Uma vez que se pretendia diferenciar com clareza as ocorrências do pronome relativo das do complementador, optouse pela não inclusão de tais sequências, já que a forma que pode corresponder a ambos. No entanto, reconhece-se agora a pertinência de incluir tais exemplos em futuros estudos, de modo a compreender se é o pronome relativo quem o responsável pelo julgamento das frases com antecedente humano como agramaticais ou se as avaliações são idênticas no caso de a frase com antecedente humano ser introduzida por que.
} 
(22) *O rapaz quem gosto é simpático.

(23) *O rapaz o qual gosto é simpático.

Para estabelecer a relação entre cortadoras e a frequência absoluta dos verbos, procurámos dar resposta à seguinte questão de investigação:

QI3: A maior ocorrência de relativas cortadoras com as combinações de $V+$ Prep referidas na literatura está relacionada com questões de frequência absoluta dos verbos na língua?

A literatura é unânime quanto à maior frequência de relativas cortadoras com um dado conjunto de combinatórias de $\mathrm{V}+$ Prep (gostar de, precisar de, falar de, necessitar de). Poderá esta relacionar-se com a frequência absoluta dos verbos que integram estas combinatórias, considerando contextos sintáticos diferentes? Para responder a esta questão, pedimos aos participantes para julgarem frases relativas cortadoras com um grupo de verbos que seleciona uma preposição argumental com uma frequência absoluta equivalente ou superior a gostar de, precisar de, falar de, necessitar de.

A seleção foi feita com base na observação da frequência absoluta de verbos que subcategorizam as preposições de e a nos corpora CETEMPúblico e CRPC (cf. gráfico 1). Para a preposição de, escolhemos esquecer-se de, lembrar-se de e recordar-se de ${ }^{8}$. Com o objetivo de testar também a preposição $a$, selecionámos as combinações chegar a e assistir a.

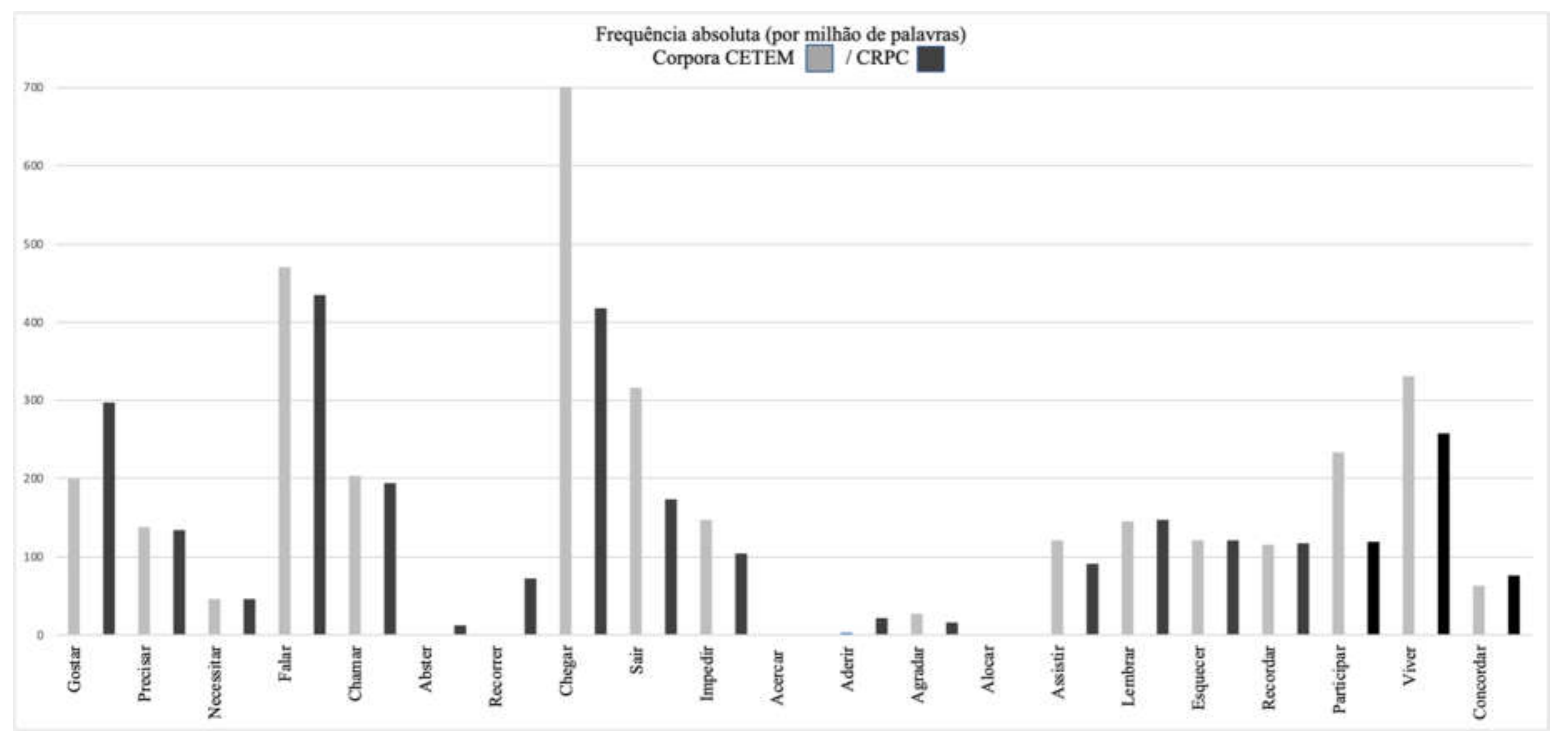

Gráfico 1: frequência absoluta (n. ${ }^{\circ}$ de instâncias por milhão de palavras) das combinatórias de V + Prep selecionadas, nos corpora CETEMPúblico e CRPC [consultados em outubro de 2019]

Finalmente, para avaliar a possibilidade de estas estruturas dependerem do peso acústico ou semântico da preposição, formulámos a quarta questão de investigação:

\footnotetext{
${ }^{8}$ Apesar de a estrutura reflexa poder interferir nos resultados obtidos nas estruturas relativas, não identificámos outros verbos que selecionem a preposição funcional de seguida de DP com frequência absoluta relevante.
} 
QI4: A maior ocorrência de relativas cortadoras nos casos referidos na literatura é uma consequência da perda de peso semântico elou fonológico das preposições?

São três os contextos considerados na sequência desta última questão de investigação. Em primeiro lugar, pretende-se verificar se os falantes aceitam o apagamento da preposição com outros verbos que também selecionam a preposição de (neste ponto, os Vs testados na QI3 e na QI4 coincidem). Em segundo lugar, analisase se os participantes aceitam que outras preposições gramaticalizadas e com reduzido peso fonológico, como $a$, não estejam realizadas, apresentando um comportamento semelhante a de. Por último, são considerados contextos em que os verbos selecionam preposições com conteúdo lexical, dotadas de maior peso semântico e/ou fonológico, tais como em e com, prevendo-se que os falantes não apresentem níveis de aceitação de frases relativas cortadoras tão elevados como com as preposições mais transparentes do ponto de vista semântico, nestes casos.

\section{Teste de juízos de aceitabilidade}

Os trabalhos existentes fundamentam as conclusões sobre a frequência destas estruturas em PE em dados recolhidos em corpora (Arim, Ramilo e Freitas, 2004; Aßmann e Rinke, 2017; Santos, 2014; Veloso, 2007, entre outros). Para este estudo, escolhemos fazer um teste de juízos de aceitabilidade (TJA), uma vez que, para responder às questões acima enunciadas, sentimos a necessidade de complementar os estudos já existentes com dados recolhidos de forma experimental. O TJA foi aplicado em papel, a um total de 79 participantes, estudantes universitários, falantes nativos de PE, com idades compreendidas entre os 17 e os 39 anos.

Para a criação do TJA, considerámos as seguintes variáveis:

- Combinações de verbo + preposição: gostar (de); precisar (de); necessitar (de); falar (de); lembrarse (de); esquecer-se (de); recordar-se (de); chamar (a); chegar (a); agradar (a); assistir (a); concordar (com); dialogar (com); participar (em); viver (em).

- $\quad$ Tipo de frase: declarativa simples vs. relativa.

- Realização lexical da preposição vs. omissão da preposição.

- Traços de humanidade do objeto (antecedente da relativa): humano vs. não humano.

As frases foram pseudo-aleatorizadas em oito blocos, quatro com quinze frases e quatro com nove frases. Os verbos testados nunca se repetiram em nenhum dos blocos. O facto de estes não terem o mesmo número de itens decorre de seis dos verbos selecionados só se poderem combinar com objetos especificados quanto a um valor de humanidade?.

Em cada bloco de frases, foi controlado o número de itens gramaticais e agramaticais, bem como o número de objetos humanos vs. não humanos, procurando manter-se um ratio equilibrado entre estes. Cada bloco foi apresentado numa folha de papel diferente. Criaram-se duas versões do teste, com diferentes organizações dos blocos de frases, de modo a controlar um efeito de cansaço dos participantes nos resultados obtidos.

Apresenta-se abaixo um exemplo de um dos blocos mostrado aos participantes:

\footnotetext{
${ }^{9}$ Agradar e dialogar só se combinam com objetos [+humanos], ao passo que assistir, chegar, participar e viver só se combinam com objetos [-humanos].
} 


\begin{tabular}{|c|c|c|c|c|}
\hline Verbo & Prep. & Tipo de frase & $\begin{array}{c}\text { Objeto }[+/-] \\
\text { humano }\end{array}$ & Item Exemplo \\
\hline Gostar & de & Declarativa simples & Não humano & O Vasco gosta de livros. \\
\hline Lembrar & $\varnothing$ & Declarativa simples & Não humano & *O médico lembrou-se uma história engraçada. \\
\hline Chamar & $\varnothing$ & Relativa & Não humano & *A instituição que o António chamou antiquada fechou as portas. \\
\hline Agradar & $\varnothing$ & Relativa & Humano & *O professor quem as mudanças agradaram foi promovido a diretor. \\
\hline Necessitar & de & Declarativa simples & Não humano & Os bolseiros de investigação necessitam de apoios adicionais. \\
\hline Precisar & $\varnothing$ & Relativa & Humano & *A amiga quem o Francisco precisa chegou hoje! \\
\hline Esquecer & $\varnothing$ & Relativa & Humano & *O paciente quem o médico se esqueceu fez uma reclamação. \\
\hline Concordar & com & Relativa & Humano & O professor com que os alunos concordaram é antipático. \\
\hline Falar & de & Declarativa simples & Humano & O Gonçalo falou de colegas ao jantar. \\
\hline Participar & em & Relativa & Não humano & O espetáculo em que a cantora participou realizou-se no Campo Pequeno. \\
\hline Dialogar & com & Declarativa simples & Humano & Os alunos dialogaram com o professor. \\
\hline Assistir & a & Declarativa simples & Não humano & Os alunos assistiram aos ensaios da peça. \\
\hline Chegar & $\varnothing$ & Declarativa simples & Não humano & *O Pedro chegou jardim. \\
\hline Viver & $\varnothing$ & Declarativa simples & Não humano & *Os amigos vivem um apartamento perto do mar. \\
\hline Recordar & $\varnothing$ & Declarativa simples & Não humano & *A avó recordou-se uma festa na sua infância. \\
\hline
\end{tabular}

Tabela 1: Exemplo de um dos blocos de frases mostrado aos participantes no TJA

Por baixo de cada uma das frases, foi colocada uma linha com $15 \mathrm{~cm}$, com a indicação "Muito natural" no extremo esquerdo, "Nada natural" no extremo direito e "Não sei" entre os 7 e os $8 \mathrm{~cm}$. Foi pedido aos participantes que assinalassem com uma cruz qual a sua intuição relativamente a cada uma das 96 frases testadas. Foi-lhes ainda dito para não voltarem atrás e para não corrigirem as respostas.

Para o tratamento dos dados, aplicou-se uma transparência com o espaçamento de $15 \mathrm{~cm}$ e as respostas dos participantes foram classificadas de acordo com a sua posição na linha (por exemplo, uma cruz colocada nos $4 \mathrm{~cm}$ corresponde a uma resposta codificada com o número 4). Nos raros casos em que a resposta se encontrava entre dois valores, foi registado o valor em que a cruz ocupava maior área.

\section{Resultados}

QI1: Os verbos que ocorrem em relativas cortadoras mostram variação no que diz respeito à categoria do complemento que selecionam?

Para responder a esta questão de investigação, analisámos os resultados obtidos nas frases declarativas simples, contrastando os juízos de aceitabilidade nas frases declarativas gramaticais, em que o verbo mantém a 
preposição subcategorizada (cf. (24)), e nas suas contrapartidas agramaticais, em que a preposição selecionada pelo verbo foi retirada (cf. (25)), como exemplificado abaixo:

(24) O médico lembrou-se de uma história engraçada.

(25) *O médico lembrou-se uma história engraçada.

Apresentam-se abaixo, na Tabela 2, os resultados obtidos por verbo:

\begin{tabular}{|c|c|c|c|c|c|c|c|c|c|c|c|c|c|c|c|c|}
\hline \multirow{2}{*}{ Verbo } & \multirow{2}{*}{ Item } & \multicolumn{3}{|c|}{ Muito natural } & \multicolumn{9}{|c|}{ Não } & \multicolumn{3}{|c|}{ Nada natural } \\
\hline & & 1 & 2 & 3 & 4 & 5 & 6 & 7 & 8 & 9 & 10 & 11 & 12 & 13 & 14 & 15 \\
\hline agradar & *As mudanças no regulamento agradaram o professor. & $38,0 \%$ & $31,6 \%$ & $3,8 \%$ & $0,0 \%$ & $1,3 \%$ & $0,0 \%$ & $1,3 \%$ & $2,5 \%$ & $1,3 \%$ & $0,0 \%$ & $0,0 \%$ & $0,0 \%$ & $1,3 \%$ & $10,1 \%$ & $8,9 \%$ \\
\hline assistir & ${ }^{*}$ Os alunos assistiram os ensaios da peça. & $5,1 \%$ & $5,1 \%$ & $0,0 \%$ & $0,0 \%$ & $1,3 \%$ & $0,0 \%$ & $3,8 \%$ & $3,8 \%$ & $3,8 \%$ & $0,0 \%$ & $2,5 \%$ & $2,5 \%$ & $3,8 \%$ & $46,8 \%$ & $21,5 \%$ \\
\hline \multirow{2}{*}{ chamar } & ${ }^{*}$ O António chamou antiquada a instituição. & $2,5 \%$ & $8,9 \%$ & $2,5 \%$ & $0,0 \%$ & $3,8 \%$ & $0,0 \%$ & $3,8 \%$ & $15,2 \%$ & $1,3 \%$ & $2,5 \%$ & $2,5 \%$ & $2,5 \%$ & $0,0 \%$ & $21,5 \%$ & $32,9 \%$ \\
\hline & ${ }^{*} O$ António chamou inteligente o aluno. & $2,5 \%$ & $3,8 \%$ & $0,0 \%$ & $0,0 \%$ & $1,3 \%$ & $1,3 \%$ & $0,0 \%$ & $3,8 \%$ & $5,1 \%$ & $0,0 \%$ & $3,8 \%$ & $5,1 \%$ & $2,5 \%$ & $38,0 \%$ & $32,9 \%$ \\
\hline chegar & ${ }^{*}$ O Pedro chegou jardim. & $7,6 \%$ & $3,8 \%$ & $0,0 \%$ & $0,0 \%$ & $0,0 \%$ & $0,0 \%$ & $0,0 \%$ & $2,5 \%$ & $0,0 \%$ & $2,5 \%$ & $2,5 \%$ & $2,5 \%$ & $2,5 \%$ & $50,6 \%$ & $25,3 \%$ \\
\hline \multirow{2}{*}{ concordar } & ${ }^{*}$ Os al unos concordaram o professor. & $2,5 \%$ & $1,3 \%$ & $2,5 \%$ & $1,3 \%$ & $0,0 \%$ & $0,0 \%$ & $1,3 \%$ & $1,3 \%$ & $2,5 \%$ & $2,5 \%$ & $1,3 \%$ & $2,5 \%$ & $3,8 \%$ & $51,9 \%$ & $25,3 \%$ \\
\hline & ${ }^{*}$ Os políticos concordaram a nova lei. & $0,0 \%$ & $12,7 \%$ & $0,0 \%$ & $3,8 \%$ & $6,3 \%$ & $0,0 \%$ & $1,3 \%$ & $11,4 \%$ & $1,3 \%$ & $2,5 \%$ & $1,3 \%$ & $1,3 \%$ & $3,8 \%$ & $15,2 \%$ & $9,2 \%$ \\
\hline dis & ${ }^{*}$ Os al unos dialogaram o professor. & & & $0,0 \%$ & $0,0 \%$ & $1,3 \%$ & $0,0 \%$ & $1,3 \%$ & $1,3 \%$ & $1,3 \%$ & $5,1 \%$ & $1,3 \%$ & $0 \%$ & $6,3 \%$ & & $4,2 \%$ \\
\hline \multirow{2}{*}{ esquecer-se } & ${ }^{*} \mathrm{O}$ Gonçalo esqueceu-se um livro em casa. & $0,0 \%$ & $3,8 \%$ & $0,0 \%$ & $2,5 \%$ & $0,0 \%$ & $0,0 \%$ & $1,3 \%$ & $2,5 \%$ & $3,8 \%$ & $3,8 \%$ & $1,3 \%$ & $5,1 \%$ & $1,3 \%$ & $50,6 \%$ & $24,1 \%$ \\
\hline & ${ }^{*} O$ médico esqueceu-se o paciente na sala. & $0,0 \%$ & $1,3 \%$ & $0,0 \%$ & $0,0 \%$ & $0,0 \%$ & $0,0 \%$ & $0,0 \%$ & $3,8 \%$ & $1,3 \%$ & $1,3 \%$ & $0,0 \%$ & $1,3 \%$ & $6,3 \%$ & $50,6 \%$ & $34,2 \%$ \\
\hline \multirow{2}{*}{ falar } & ${ }^{*} \mathrm{O}$ Gonçalo falou colegas ao jantar. & $0,0 \%$ & $3,8 \%$ & $0,0 \%$ & $1,3 \%$ & $1,3 \%$ & $0,0 \%$ & $0,0 \%$ & $0,0 \%$ & $1,3 \%$ & $2,5 \%$ & $0,0 \%$ & $2,5 \%$ & $2,5 \%$ & $27,8 \%$ & $57,0 \%$ \\
\hline & ${ }^{*} O$ Gonçalo falou temas interessantes ao jantar. & $10,1 \%$ & $3,8 \%$ & $1,3 \%$ & $6,3 \%$ & $2,5 \%$ & $1,3 \%$ & $5,1 \%$ & $10,1 \%$ & $2,5 \%$ & $1,3 \%$ & $5,1 \%$ & $2,5 \%$ & $2,5 \%$ & $27,8 \%$ & $17,7 \%$ \\
\hline \multirow{2}{*}{ gostar } & ${ }^{*} \mathrm{O}$ Vasco gosta amigos da escola. & $2,5 \%$ & $0,0 \%$ & $0,0 \%$ & $0,0 \%$ & $0,0 \%$ & $0,0 \%$ & $0,0 \%$ & $0,0 \%$ & $5,1 \%$ & $0,0 \%$ & $2,5 \%$ & $3,8 \%$ & $2,5 \%$ & $62,0 \%$ & $21,5 \%$ \\
\hline & ${ }^{*} O$ Vasco gosta livros. & $2,5 \%$ & $5,1 \%$ & $0,0 \%$ & $0,0 \%$ & $0,0 \%$ & $0,0 \%$ & $1,3 \%$ & $3,8 \%$ & $1,3 \%$ & $1,3 \%$ & $3,8 \%$ & $2,5 \%$ & $1,3 \%$ & $35,4 \%$ & $41,8 \%$ \\
\hline \multirow{2}{*}{ lembrar-se } & *O Francisco lembrou-se uma amiga do Jardim de Infância. & $6,3 \%$ & $7,6 \%$ & $0,0 \%$ & $0,0 \%$ & $0,0 \%$ & $0,0 \%$ & $1,3 \%$ & $2,5 \%$ & $1,3 \%$ & $2,5 \%$ & $2,5 \%$ & $3,8 \%$ & $5,1 \%$ & $31,6 \%$ & $35,4 \%$ \\
\hline & *O médico lembrou-se uma história engraçada. & $6,3 \%$ & $13,9 \%$ & $0,0 \%$ & $0,0 \%$ & $0,0 \%$ & $1,3 \%$ & $1,3 \%$ & $5,1 \%$ & $1,3 \%$ & $0,0 \%$ & $3,8 \%$ & $2,5 \%$ & $3,8 \%$ & $17,7 \%$ & $43,0 \%$ \\
\hline \multirow{2}{*}{ necessitar } & ${ }^{*}$ O Pedro necessita uma namorada. & $3,8 \%$ & $7,6 \%$ & $1,3 \%$ & $0,0 \%$ & $1,3 \%$ & $1,3 \%$ & $0,0 \%$ & $5,1 \%$ & $2,5 \%$ & $1,3 \%$ & $2,5 \%$ & $3,8 \%$ & $6,3 \%$ & $32,9 \%$ & $30,4 \%$ \\
\hline & ${ }^{*}$ Os bolseiros de investigação necessitam apoios adicionais & $12,7 \%$ & $12,7 \%$ & $3,8 \%$ & $1,3 \%$ & $0,0 \%$ & $1,3 \%$ & $6,3 \%$ & $10,1 \%$ & $1,3 \%$ & $2,5 \%$ & $1,3 \%$ & $0,0 \%$ & $2,5 \%$ & $25,3 \%$ & $19,0 \%$ \\
\hline participar & *A cantora participou um espetáculo no Campo Pequeno. & $5,1 \%$ & $5,1 \%$ & $0,0 \%$ & $1,3 \%$ & $1,3 \%$ & $1,3 \%$ & $1,3 \%$ & $0,0 \%$ & $3,8 \%$ & $0,0 \%$ & $2,5 \%$ & $2,5 \%$ & $2,5 \%$ & $49,4 \%$ & $24,1 \%$ \\
\hline \multirow{2}{*}{ precisar } & ${ }^{*}$ O Francisco precisa uma amiga para brincar. & $17,7 \%$ & $6,3 \%$ & $1,3 \%$ & $0,0 \%$ & $1,3 \%$ & $0,0 \%$ & $1,3 \%$ & $3,8 \%$ & $1,3 \%$ & $1,3 \%$ & $1,3 \%$ & $3,8 \%$ & $5,1 \%$ & $40,5 \%$ & $15,2 \%$ \\
\hline & * OFrancisco precisa uma mochila. & $7,6 \%$ & $6,3 \%$ & $0,0 \%$ & $0,0 \%$ & $0,0 \%$ & $0,0 \%$ & $1,3 \%$ & $2,5 \%$ & $1,3 \%$ & $0,0 \%$ & $5,1 \%$ & $5,1 \%$ & $2,5 \%$ & $29,1 \%$ & $39,2 \%$ \\
\hline \multirow{2}{*}{ recordar } & *A avó recordou-se uma festa na sua infância. & $2,5 \%$ & $0,0 \%$ & $0,0 \%$ & $0,0 \%$ & $2,5 \%$ & $2,5 \%$ & $1,3 \%$ & $3,8 \%$ & $1,3 \%$ & $0,0 \%$ & $2,5 \%$ & $2,5 \%$ & $5,1 \%$ & $55,7 \%$ & $20,3 \%$ \\
\hline & ${ }^{*} \mathrm{O}$ tio recordou-se os sobrinhos pequenos & $1,3 \%$ & $1,3 \%$ & $0,0 \%$ & $0,0 \%$ & $0,0 \%$ & $0,0 \%$ & $2,5 \%$ & $3,8 \%$ & $2,5 \%$ & $1,3 \%$ & $3,8 \%$ & $2,5 \%$ & $1,3 \%$ & $55,7 \%$ & $24,1 \%$ \\
\hline viver & ${ }^{*}$ Os amigos vivem um apartamento perto do mar. & $3,8 \%$ & $1,3 \%$ & $0,0 \%$ & $2,5 \%$ & $0,0 \%$ & $1,3 \%$ & $0,0 \%$ & $2,5 \%$ & $2,5 \%$ & $1,3 \%$ & $1,3 \%$ & $3,8 \%$ & $2,5 \%$ & $49,4 \%$ & $27,8 \%$ \\
\hline
\end{tabular}

Tabela 2: Resultados percentuais obtidos por V, considerando as frases declarativas simples em que a preposição

selecionada pelo verbo foi omitida

Apesar de a maioria dos participantes julgar como "nada naturais"10 frases declarativas simples com grande parte das combinatórias de V + Prep em que a preposição selecionada pelo verbo foi omitida, há cinco casos que contrastam com os restantes, relativamente aos quais os participantes mostram variação na aceitabilidade: agradar, necessitar, precisar, lembrar-se e falar.

Dito de outra forma, as frases testadas mostram percentagens relevantes de falantes que as consideram "muito naturais": a frase (26) é considerada por quase $30 \%$ dos inquiridos como "muito natural"; o exemplo (27) é "muito natural" para 25\% dos inquiridos; (28) é classificada como "muito natural" por 20\% dos participantes e (29) é "muito natural" para $15 \%$ dos participantes.

(26) *Os bolseiros de investigação necessitam apoios adicionais.

(27) * O Francisco precisa uma amiga para brincar.

(28) *O médico lembrou-se uma história engraçada.

(29) * O Gonçalo falou temas interessantes ao jantar.

\footnotetext{
${ }^{10} \mathrm{Na}$ nossa análise, consideramos que as frases que foram classificadas pelos participantes nos primeiros $3 \mathrm{~cm}$ da linha são consideradas "muito naturais" e que as frases classificadas nos últimos $3 \mathrm{~cm}$ (13-15) são consideradas "nada naturais".
} 
Com o verbo agradar, a maioria dos inquiridos (73\%) aceitou como muito natural uma frase declarativa não preposicionada (cf. (30)), havendo $20 \%$ dos participantes a rejeitar esta construção:

(30) ? As mudanças no regulamento agradaram o professor.

QI2: As cortadoras são introduzidas por um pronome relativo ou por um complementador?

Para testar esta questão, introduzimos frases relativas iniciadas pelo pronome relativo quem no nosso juízo de aceitabilidade, tais como (31) e (32):

(31) *Os sobrinhos quem o tio se recordou já são adultos.

(32) *Os amigos quem o Vasco gosta são divertidos.

Apresentamos abaixo os principais resultados obtidos nas frases relativas cortadoras com o pronome relativo quem:

\begin{tabular}{|c|c|c|c|c|c|c|c|c|c|c|c|c|c|c|c|c|}
\hline Verbo & Item & \multicolumn{3}{|c|}{ Muito natural } & \multicolumn{9}{|c|}{ Não sei } & \multicolumn{3}{|c|}{ Nada natural } \\
\hline esquecer- & * O paciente quem o médico se esqueceu fez uma reclamação. & $2,6 \%$ & $3,8 \%$ & $0,0 \%$ & $0,0 \%$ & $1,3 \%$ & $1,3 \%$ & $1,3 \%$ & $3,8 \%$ & $1,3 \%$ & $1,3 \%$ & $2,6 \%$ & $3,8 \%$ & $2,6 \%$ & $46,2 \%$ & $28,2 \%$ \\
\hline falar & * Os colegas quem o Gonçalo falou são simpáticos & $0,0 \%$ & $2,5 \%$ & $0,0 \%$ & $0,0 \%$ & $0,0 \%$ & $0,0 \%$ & $1,3 \%$ & $5,1 \%$ & $2,5 \%$ & $2,5 \%$ & $2,5 \%$ & $3,8 \%$ & $5,1 \%$ & $48,1 \%$ & $26,6 \%$ \\
\hline gostar & ${ }^{*}$ Os amigos quem o Vasco gosta são divertidos & $1,3 \%$ & $2,5 \%$ & $1,3 \%$ & $0,0 \%$ & $0,0 \%$ & $1,3 \%$ & $3,8 \%$ & $3,8 \%$ & $2,5 \%$ & $2,5 \%$ & $0,0 \%$ & $2,5 \%$ & $2,5 \%$ & $59,5 \%$ & $16,5 \%$ \\
\hline precisar & ${ }^{*} A$ amiga quem o Francisco precisa chegou hoje! & $0,0 \%$ & $1,3 \%$ & $0,0 \%$ & $0,0 \%$ & $1,3 \%$ & $0,0 \%$ & $1,3 \%$ & $6,3 \%$ & $1,3 \%$ & $3,8 \%$ & $2,5 \%$ & $0,0 \%$ & $3,8 \%$ & $49,4 \%$ & $29,1 \%$ \\
\hline recordar-se & * Os sobrinhos quem o tio se recordou já são adultos. & {$[0,0 \%$} & $5,1 \%$ & {$[0,0 \%$} & $\mid 1,3 \%$ & $\mid 0,0 \%$ & {$[1,3 \%$} & $1,3 \%$ & $\{2,5 \%$ & $2,5 \%$ & {$[1,3 \%$} & {$[2,5 \%$} & $3,8 \%$ & $6,3 \%$ & $25,3 \%$ & $46,8 \%$ \\
\hline
\end{tabular}

Tabela 3: Resultados percentuais obtidos por V, considerando as frases relativas cortadoras com antecedente humano, introduzidas pelo pronome relativo quem

Neste caso, os inquiridos foram unânimes na rejeição, confirmando que o elemento que introduz as frases relativas cortadoras é um complementador e não um pronome relativo, tal como havia já sido referido na literatura (Peres e Móia, 1995, Alexandre e Hagemeijer, 2013, entre outros).

QI3: A maior ocorrência de relativas cortadoras com as combinações de $V+$ Prep referidas na literatura (gostar de, precisar de, falar de, necessitar de) está relacionada com questões de frequência absoluta dos verbos na lingua?

Para responder a esta questão de investigação, testámos verbos que selecionam a preposição de e $a$ com uma frequência absoluta em corpora comparável à daqueles que são identificados como mais propensos à ocorrência de cortadoras.

Apresentam-se na Tabela 4, abaixo, os resultados globais obtidos por V para as frases relativas cortadoras: 


\begin{tabular}{|c|c|c|c|c|c|c|c|c|c|c|c|c|c|c|c|c|}
\hline \multirow[b]{2}{*}{ Verbo } & \multirow[b]{2}{*}{ Item } & \multicolumn{3}{|c|}{ Muito natural } & \multicolumn{9}{|c|}{ Não œi } & \multicolumn{3}{|c|}{ Nada natural } \\
\hline & & 1 & 2 & 3 & 4 & 5 & 6 & 7 & 8 & 9 & 10 & 11 & 12 & 13 & 14 & 15 \\
\hline agradar & $\begin{array}{l}\text { *O professor quem as mudanças agradaram foi promovido a } \\
\text { diretor. }\end{array}$ & $0,0 \%$ & $3,8 \%$ & $1,3 \%$ & $0,0 \%$ & $0,0 \%$ & $0,0 \%$ & $1,3 \%$ & $5,1 \%$ & $2,5 \%$ & $2,5 \%$ & $5,1 \%$ & $2,5 \%$ & $6,3 \%$ & $32,9 \%$ & $36,7 \%$ \\
\hline assistir & "Os ensaios que os al unos assistiram correram muito bem. & $28,2 \%$ & $33,3 \%$ & $6,4 \%$ & $0,0 \%$ & $2,6 \%$ & $1,3 \%$ & $2,6 \%$ & $6,4 \%$ & $0,0 \%$ & $0,0 \%$ & $2,6 \%$ & $0,0 \%$ & $1,3 \%$ & $7,7 \%$ & $7,7 \%$ \\
\hline \multirow{2}{*}{ chamar } & *A instituicão que o António chamou antiquada fechou as portas & $22,8 \%$ & $31,6 \%$ & $3,8 \%$ & $3,8 \%$ & $2,5 \%$ & $0,0 \%$ & $1,3 \%$ & $7,6 \%$ & $2,5 \%$ & $2,5 \%$ & $2,5 \%$ & $5,1 \%$ & $0,0 \%$ & $8,9 \%$ & $5,1 \%$ \\
\hline & $\begin{array}{l}\text { *O al uno quem o António chamou inteligente teve a mel hor nota } \\
\text { da turma. }\end{array}$ & $5,1 \%$ & $6,3 \%$ & $0,0 \%$ & $0,0 \%$ & $0,0 \%$ & $3,8 \%$ & $5,1 \%$ & $7,6 \%$ & $1,3 \%$ & $2,5 \%$ & $2,5 \%$ & $1,3 \%$ & $2,5 \%$ & $38,0 \%$ & $24,1 \%$ \\
\hline chegar & *O jardim que o Pedro chegou é bonito. & $5,1 \%$ & $8,9 \%$ & $0,0 \%$ & $1,3 \%$ & $0,0 \%$ & $0,0 \%$ & $2,5 \%$ & $6,3 \%$ & $2,5 \%$ & $3,8 \%$ & $1,3 \%$ & $1,3 \%$ & $3,8 \%$ & $25,3 \%$ & $38,0 \%$ \\
\hline \multirow{2}{*}{ concordar } & *A lei que os políticos concordaram é polémica. & $24,1 \%$ & $27,8 \%$ & $1,3 \%$ & $2,5 \%$ & $2,5 \%$ & $0,0 \%$ & $1,3 \%$ & $6,3 \%$ & $1,3 \%$ & $1,3 \%$ & $3,8 \%$ & $0,0 \%$ & $0,0 \%$ & $10,1 \%$ & $17,7 \%$ \\
\hline & mascomoram & $2,5 \%$ & $7,6 \%$ & $0,0 \%$ & $0,0 \%$ & $1,3 \%$ & $0,0 \%$ & $3,8 \%$ & $3,8 \%$ & $1,3 \%$ & $1,3 \%$ & $1,3 \%$ & $2,5 \%$ & $3,8 \%$ & $35,4 \%$ & $35,4 \%$ \\
\hline dialogar & * O professor que os al unos di alogaram é atencioso. & $3,8 \%$ & $10,1 \%$ & $2,5 \%$ & $0,0 \%$ & $1,3 \%$ & $0,0 \%$ & $1,3 \%$ & $6,3 \%$ & $1,3 \%$ & $0,0 \%$ & $3,8 \%$ & $3,8 \%$ & $3,8 \%$ & $35,4 \%$ & $26,6 \%$ \\
\hline \multirow{2}{*}{$\begin{array}{l}\text { esquecer- } \\
\text { se }\end{array}$} & "O livro que o Gonçalo se esqueceu era essencial par & $49,4 \%$ & $19,0 \%$ & $7,6 \%$ & $2,5 \%$ & $1,3 \%$ & $1,3 \%$ & $1,3 \%$ & $5,1 \%$ & $0,0 \%$ & $0,0 \%$ & $0,0 \%$ & $1,3 \%$ & $0,0 \%$ & $6,3 \%$ & $5,1 \%$ \\
\hline & èm o médico se & $2,6 \%$ & $3,8 \%$ & $0,0 \%$ & $0,0 \%$ & $1,3 \%$ & $1,3 \%$ & $1,3 \%$ & $3,8 \%$ & $1,3 \%$ & $1,3 \%$ & $2,6 \%$ & $3,8 \%$ & $2,6 \%$ & $46,2 \%$ & $28,2 \%$ \\
\hline \multirow{2}{*}{ falar } & "Os colegas quem o Gonçalo falou são simpáticos & $0,0 \%$ & $2,5 \%$ & $0,0 \%$ & $0,0 \%$ & $0,0 \%$ & $0,0 \%$ & $1,3 \%$ & $5,1 \%$ & $2,5 \%$ & $2,5 \%$ & $2,5 \%$ & $3,8 \%$ & $5,1 \%$ & $48,1 \%$ & $26,6 \%$ \\
\hline & * Os temas que o Gonçalo falou ao jantar são interessantes. & $21,5 \%$ & $41,8 \%$ & $2,5 \%$ & $3,8 \%$ & $5,1 \%$ & $1,3 \%$ & $1,3 \%$ & $0,0 \%$ & $2,5 \%$ & $0,0 \%$ & $1,3 \%$ & $0,0 \%$ & $1,3 \%$ & $6,3 \%$ & $11,4 \%$ \\
\hline \multirow{2}{*}{ gostar } & "Os livros que o Vasco gosta são interessantes & $38,0 \%$ & $39,2 \%$ & $6,3 \%$ & $1,3 \%$ & $3,8 \%]$ & $0,0 \%$ & $2,5 \%$ & $5,1 \%$ & $0,0 \%$ & $0,0 \%$ & $0,0 \%$ & $0,0 \%$ & $0,0 \%$ & $0,0 \%$ & $3,8 \%$ \\
\hline & *Os amigos quem o Vasco gosta são divertidos. & $1,3 \%$ & $2,5 \%$ & $1,3 \%$ & $0,0 \%$ & {$[0,0 \%]$} & $1,3 \%$ & $3,8 \%$ & $3,8 \%$ & $2,5 \%$ & $2,5 \%$ & $0,0 \%$ & $2,5 \%$ & $2,5 \%$ & $59,5 \%$ & $16,5 \%$ \\
\hline \multirow{2}{*}{ lembrar-se } & "A história que o médico se lembrou é engraçada. & $35,4 \%$ & $27,8 \%$ & $6,3 \%$ & $1,3 \%$ & $2,5 \%$ & $1,3 \%$ & $1,3 \%$ & $6,3 \%$ & $1,3 \%$ & $1,3 \%$ & $0,0 \%$ & $1,3 \%$ & $1,3 \%$ & $8,9 \%$ & $3,8 \%$ \\
\hline & " $A$ amiga quem o Francisco se lembrou é muito gira. & $2,5 \%$ & $3,8 \%$ & $0,0 \%$ & $0,0 \%$ & $0,0 \%$ & $1,3 \%$ & $0,0 \%$ & $6,3 \%$ & $3,8 \%$ & $2,5 \%$ & $0,0 \%$ & $3,8 \%$ & $3,8 \%$ & $49,4 \%$ & $22,8 \%$ \\
\hline necessitar & " A namorada quem o Pedro necessita tem de ser paciente. & $1,3 \%$ & $2,5 \%$ & $1,3 \%$ & $0,0 \%$ & $0,0 \%$ & $0,0 \%$ & $1,3 \%$ & $1,3 \%$ & $3,8 \%$ & $1,3 \%$ & $5,1 \%$ & $1,3 \%$ & $1,3 \%$ & $51,9 \%$ & $27,8 \%$ \\
\hline participar & $\begin{array}{l}\text { ¿O espetáculo que a cantora participou realizou-se no Campo } \\
\text { Pequeno. }\end{array}$ & 35,4 & 15,2 & $3,8 \%$ & $1,3 \%$ & $0,0 \%$ & $3,8 \%$ & $2,5 \%$ & $3,8 \%$ & $1,3 \%$ & $3,8 \%$ & $5,1 \%$ & $1,3 \%$ & $0,0 \%$ & $16,5 \%$ & $6,3 \%$ \\
\hline \multirow{3}{*}{ precisar } & *A mochila que o Francisco precisa é cara! & $53,2 \%$ & $35,4 \%$ & $2,5 \%$ & $1,3 \%$ & $1,3 \%$ & $0,0 \%$ & $0,0 \%$ & $1,3 \%$ & $0,0 \%$ & $0,0 \%$ & $0,0 \%$ & $0,0 \%$ & $0,0 \%$ & $3,8 \%$ & $1,3 \%$ \\
\hline & "A amiga quem o Francisco precisa chegou hoje! & $0,0 \%$ & $1,3 \%$ & $0,0 \%$ & $0,0 \%$ & $1,3 \%$ & $0,0 \%$ & $1,3 \%$ & $6,3 \%$ & $1,3 \%$ & $3,8 \%$ & $2,5 \%$ & $0,0 \%$ & $3,8 \%$ & $49,4 \%$ & $29,1 \%$ \\
\hline & $\begin{array}{l}\text { *Os apoios que os bolseiros precisam não foram concedidos pel } \\
\text { governo. }\end{array}$ & $41,8 \%$ & $39,2 \%$ & $5,1 \%$ & $1,3 \%$ & $2,5 \%$ & $0,0 \%$ & $1,3 \%$ & $2,5 \%$ & $0,0 \%$ & $0,0 \%$ & $0,0 \%$ & $0,0 \%$ & $0,0 \%$ & $5,1 \%$ & $1,3 \%$ \\
\hline \multirow{2}{*}{$\begin{array}{c}\text { recordar- } \\
\text { se }\end{array}$} & "Os sobrinhos quem o tio se recordou já são adultos & $0,0 \%$ & $5,1 \%$ & $0,0 \%$ & $1,3 \%$ & $0,0 \%$ & $1,3 \%$ & $1,3 \%$ & $2,5 \%$ & $2,5 \%$ & $1,3 \%$ & $2,5 \%$ & $3,8 \%$ & $6,3 \%$ & $25,3 \%$ & $46,8 \%$ \\
\hline & * A festa que a avó se recordou foi marcante para todos & $17,7 \%$ & $36,7 \%$ & $3,8 \%$ & $2,5 \%$ & $2,5 \%$ & $2,5 \%$ & $0,0 \%$ & $8,9 \%$ & $0,0 \%$ & $1,3 \%$ & $2,5 \%$ & $0,0 \%$ & $2,5 \%$ & $12,7 \%$ & $6,3 \%$ \\
\hline viver & " $O$ apartamento que os amigos vivem é espaçoso. & $10,1 \%$ & $6,3 \%$ & $2,5 \%$ & $0,0 \%$ & $1,3 \%$ & $0,0 \%$ & $3,8 \%$ & $11,4 \%$ & $1,3 \%$ & $2,5 \%$ & $3,8 \%$ & $5,1 \%$ & $0,0 \%$ & $39,2 \%$ & $12,7 \%$ \\
\hline
\end{tabular}

Tabela 4: Resultados globais percentuais obtidos por $\mathrm{V}$, considerando as frases relativas cortadoras

Os resultados mostram-nos que a maioria dos participantes no estudo aceita relativas cortadoras introduzidas por que com os verbos esquecer-se (76\%) (cf. (33)), lembrar-se (70\%) (cf. (34)), e, embora de forma não tão expressiva, recordar-se (58\%) (cf. (35)), considerando gramaticais frases como as exemplificadas abaixo:

(33) ? O livro que o Gonçalo se esqueceu era essencial para a aula.

(34) ? A história que o médico se lembrou é engraçada.

(35) ? A festa que a avó se recordou foi marcante para todos.

No entanto, com a combinação chegar $a$, os resultados são opostos, com a grande maioria dos participantes a rejeitar a frase (36), eventualmente devido à inacusatividade do verbo chegar ou ao valor expressivo de alvo que a preposição $a$ denota neste caso:

(36) *O jardim que o Pedro chegou é bonito.

QI4: A maior ocorrência de relativas cortadoras nos casos referidos na literatura é uma consequência da perda de peso semântico elou fonológico das preposições?

Para responder a esta questão de investigação, analisámos os resultados obtidos com verbos não habitualmente associados a relativas cortadoras na literatura, mas que também selecionam as preposições de + DP, $a+\mathrm{DP}, e m+\mathrm{DP}$ e com + DP, nomeadamente com as combinações esquecer-se de, lembrar-se de, recordarse de; assistir a, agradar a, chegar a; viver em, participar em; concordar com, dialogar com. 
Predissemos, em primeiro lugar, que as cortadoras ocorreriam com verbos diferentes de gostar, precisar, necessitar e falar que selecionam a mesma preposição de. Esta predição verificou-se parcialmente, com parte dos falantes a considerar "muito naturais" frases como (33), (34) e (35) (cf. supra).

Em segundo lugar, previmos que outras preposições gramaticalizadas e com reduzido peso fonológico apresentariam um comportamento semelhante. Observámos em maior detalhe os resultados obtidos com as combinações em que a preposição é fonológica e semanticamente menos saliente, tais como assistir a e agradar $a$ (uma vez que a preposição $a$ selecionada pelo verbo chegar tem um valor semântico expressivo, locativo).

Neste ponto, os resultados são antagónicos. $68 \%$ dos participantes considera muito natural uma relativa cortadora com o verbo assistir:

(37) ? Os ensaios que os alunos assistiram correram muito bem.

Pelo contrário, com o verbo agradar, apenas $5 \%$ dos inquiridos considera muito natural a frase cortadora, tendo a larga maioria (76\%) considerado a frase (38) nada natural.

(38) * O professor quem as mudanças agradaram foi promovido a diretor.

Apesar de as razões para este contraste ainda estarem por apurar, pensamos que este se possa dever ao facto de a cortadora com o verbo agradar ter sido apresentada com o pronome relativo quem, uma vez que os falantes não parecem aceitar uma relativa cortadora introduzida por este pronome (cf. os resultados da QI2) ${ }^{11}$. Por outro lado, embora a preposição subcategorizada por estes verbos seja a mesma, atribui Casos diferentes: com o verbo assistir, a preposição a marca o Caso oblíquo; com agradar, a marca o Caso dativo.

Por último, esperávamos que os participantes não aceitassem relativas cortadoras com verbos que selecionam preposições com conteúdo lexical, dotadas de maior peso semântico e/ou fonológico, tais como com e $e m$.

Não obstante, os dados obtidos não são uniformes nas diferentes combinações de V + Prep testadas, havendo mesmo divergências nos juízos de aceitabilidade para o mesmo verbo. Com efeito, a maioria dos inquiridos não aceita frases cortadoras com a combinação dialogar com, havendo 66\% a considerar a frase (39) "nada natural" e apenas $16 \%$ a classificá-la como "muito natural", estando os restantes $18 \%$ distribuídos pelos restantes pontos da escala, mostrando alguma indecisão na classificação.

(39) *O professor que os alunos dialogaram é atencioso.

Em relação a viver em, parece haver uma tendência de rejeição das relativas cortadoras, apesar de não ser tão expressiva como com dialogar com. 52\% considera a frase (40) "nada natural", sendo esta classificada como "muito natural" por $19 \%$ dos inquiridos. Os restantes $29 \%$ mostram a sua indecisão (significativamente, $11 \%$ destes $29 \%$ escolheram a opção central, "não sei”).

(40) *O apartamento que os amigos vivem é espaçoso.

Relativamente a participar em, os inquiridos mostram uma tendência para a aceitação de frases cortadoras. Com efeito, 54\% consideraram a frase (41) "muito natural", 23\% classificam-na como "nada natural" e os restantes $23 \%$ mostram a sua indecisão optando por classificações centrais.

\footnotetext{
${ }^{11}$ Possivelmente, os resultados teriam sido diferentes se a mesma frase tivesse sido apresentada com o relativizador que (??O professor que as mudanças agradaram foi promovido a diretor), mas, neste teste, não foram incluídas sistematicamente frases com antecedente humano e o relativizador que, uma vez que um dos objetivos era precisamente testar exemplos com um pronome relativo. Dada a ambiguidade da forma que enquanto pronome e complementador, o pronome relativo quem foi preferido nos exemplos em que o antecedente é humano. Não obstante, em estudos futuros, valerá a pena explorar se relativas cortadoras com antecedentes humanos são aceites com a forma que ou se o traço [+humano] do antecedente interfere na aceitabilidade destas estruturas.
} 
(41) ? O espetáculo que a cantora participou realizou-se no Campo Pequeno.

Por último, concordar com não apresenta homogeneidade. Com antecedente humano, os participantes rejeitam a cortadora, tendo $75 \%$ dos participantes considerado a frase (42) "nada natural". Com antecedente não humano (cf. (43)), 53\% dos inquiridos classificam a combinatória concordar com como "muito natural".

(42) *O professor que os alunos concordaram é simpático.

(43) ? A lei que os políticos concordaram é polémica.

\section{Discussão dos resultados}

A nossa primeira questão de investigação focou-se no estudo das propriedades de seleção dos verbos com que as relativas cortadoras são mais frequentes: precisar de, necessitar de, gostar de, falar de e chamar a. Assumimos que, se os falantes não aceitassem a ausência da preposição com os mesmos verbos em frases declarativas simples, a preposição integraria a numeração da estrutura relativa cortadora, sendo apagada antes ou depois do movimento do DP, ou, num cenário em que a relativa cortadora não apresentasse movimento do DP, a preposição faria parte da estrutura, com um pronome ressuntivo nulo, e seria depois apagada.

Pelo contrário, se os falantes aceitassem a queda da preposição em frases declarativas simples, sem relativas, tal seria indicativo de que, nas relativas cortadoras, a preposição não integra o DP antecedente por não ser selecionada pelo verbo, podendo estas frases ter uma derivação semelhante à proposta para as relativas de OD por Brito (1991).

O estudo do comportamento destes verbos em estruturas sintáticas diferentes (declarativas simples e relativas) pretendia, assim, tirar conclusões sobre eventuais alterações na grelha argumental dos mesmos, que seriam mais consistentes caso se verificassem num contexto diferente do da relativização (até porque a ocorrência destes verbos em frases declarativas será muito mais frequente do que em contextos relativizados). Não obstante, tratando-se de construções distintas, o comportamento do verbo numa delas não é necessariamente idêntico na outra, como veremos mais adiante.

Desta forma, testámos frases declarativas com e sem preposição (gramaticais e agramaticais), com os verbos precisar de, necessitar de, gostar de, falar de e chamar a. Para além destes, incluímos na nossa análise verbos com propriedades de seleção gramatical semelhantes, tais como lembrar-se de, esquecer-se de, recordar-se de e agradar a.

Observámos que, com cinco dos verbos testados, houve alguma variação nos juízos de aceitabilidade dos falantes, nomeadamente com os verbos agradar, necessitar, precisar, lembrar-se e falar.

Se nos ativermos no comportamento sintático de precisar, necessitar e gostar, verificamos que estes têm propriedades de seleção não homogéneas (Duarte, 2003: 636-637). Apesar de selecionarem completivas finitas não preposicionadas, estas não podem ser substituídas por um clítico acusativo, mostrando que estes Vs são casualmente defetivos:

(44) a. O João gosta que a Maria toque flauta.

b. *O João gosta-o.

(Duarte, 2003:636-637)

Quando selecionam um complemento que exige Caso (DPs e Infinitivas), precisam de ser legitimados pela preposição "usada tipicamente para marcar Caso em português, a preposição 'de"” (Duarte 2003:637):

(45) O João gosta de tocar flauta. 
Três dos verbos testados - lembrar-se, recordar-se e esquecer-se - parecem ter um comportamento semelhante, apesar de pronominais. Podem selecionar completivas finitas não preposicionadas, mas estas não podem ser substituídas por um clítico acusativo:

(47) a. O João lembra-se que a Maria tem aula de piano.

b. *O João lembra-se-o.

Quando selecionam um complemento que exige Caso (DPs e Infinitivas), precisam de ser legitimados pela preposição de:

(48) O João lembra-se da Maria.

(49) O João lembra-se de passar férias na praia.

O verbo falar seleciona uma preposição (de, com, sobre), como ilustram os enunciados abaixo:

(50) O Pedro falou do novo livro de José Luís Peixoto.

(51) O Manuel falou com a Rita ao telefone.

(52) A Paula falou sobre o novo programa na TV.

Não obstante, identificámos diversas ocorrências em corpora em que este verbo subcategoriza uma frase completiva finita, possivelmente por analogia com o verbo declarativo dizer:

(53) «O Sr. Ministro falou que tem feito um sério esforço para recuperação de dívida.»

CRPC, A144320

(54) «"Ainda eu andava na barriga da minha mãe e já se falava que o Casal Ventoso ia abaixo", afirmou um residente, de 51 anos de idade.»

CETEMPúblico, par=ext236374-soc-95a-2

Agradar seleciona um complemento preposicionado com o Caso dativo:

(55) Os livros agradaram ao editor.

Este complemento também pode ocorrer na forma de pronome clítico e o argumento externo do verbo pode ser realizado como uma completiva, tal como exemplificado em (56):

(56) Agrada-me que venhas mais cedo amanhã.

Assim, precisar, necessitar e gostar, mas também lembrar-se, recordar-se e esquecer-se selecionam completivas finitas não preposicionadas. Falar, embora não canonicamente, mostra um comportamento semelhante. Agradar pode apresentar o complemento preposicionado contraído na forma de um clítico, seguido de uma completiva finita. Será que o facto de estes verbos selecionarem complementos frásicos não preposicionados resulta num input ambíguo para os falantes, conduzindo à alteração das propriedades de seleção dos mesmos, evidenciada em frases declarativas simples?

Os dados recolhidos neste estudo exploratório levam-nos a responder negativamente a esta questão, uma vez que os falantes não apresentam juízos homogéneos quanto à omissão da preposição em frases declarativas 
simples com os verbos referidos. Dito de outra forma, a queda da preposição em frases declarativas simples não é igualmente aceite em todas as combinatórias de V + Prep. Se estabelecêssemos uma escala de aceitabilidade da omissão da preposição, com base nos dados recolhidos neste estudo, agradar estaria num extremo, com elevada aceitação da frase declarativa não preposicionada; próximos estariam precisar, necessitar e lembrarse, também com elevado grau de aceitação. Falar ocuparia uma posição intermédia. Gostar, esquecer-se e recordar-se encontrar-se-iam no extremo oposto:

\begin{tabular}{|c|c|c|c|}
\hline Agradar a & $\begin{array}{l}\text { Precisar de } \\
\text { Necessitar de } \\
\text { Lembrar-se de }\end{array}$ & Falar de & $\begin{array}{l}\text { Gostar de } \\
\text { Esquecer-se de } \\
\text { Recordar-se de }\end{array}$ \\
\hline
\end{tabular}

+ corte de Prep

- corte de Prep

Os dados recolhidos parecem apontar para a existência de gramáticas em competição. Ou seja, nos casos em que há maior aceitação da queda da preposição, tais como agradar, precisar, necessitar e falar, podemos estar perante a coexistência de duas grelhas argumentais:

(57) a. V + Prep + DP

b. $\mathrm{V}+\mathrm{DP}$

Neste caso, os falantes que aceitam a queda da preposição em frases declarativas, refletindo a grelha argumental (57b.), não realizam "verdadeiras" cortadoras, mas frases relativas de objeto direto, pois para estes a preposição não fará parte da grelha argumental do verbo. Com efeito, verificou-se que os participantes deste estudo que aceitam o apagamento da preposição na frase que não inclui relativa, aceitam a mesma frase declarativa simples com preposição e avaliam positivamente as duas frases relativas, canónica e cortadora ${ }^{12}$, mostrando duas gramáticas em coexistência. Tal significa que, com estes verbos, o mesmo output (relativa cortadora) pode ter duas gramáticas subjacentes, com grelhas argumentais distintas, à semelhança do que acontece, por exemplo, no português de São Tomé (ver Gonçalves, 2010).

Ainda assim, a relação entre a queda da preposição nas frases declarativas e as relativas cortadoras não é clara. Prova disso é o facto de os inquiridos não aceitaram frases declarativas simples com o verbo gostar, se a preposição selecionada pelo verbo não estiver expressa, sendo este um dos verbos com que as relativas cortadoras são mais bem aceites pelos falantes. Por outro lado, os participantes rejeitaram a relativa cortadora com o verbo agradar (cf. (38), "nada natural" para 76\% dos participantes), caso em que a frase declarativa simples com omissão da preposição selecionada (a) teve uma das aceitações mais expressivas (cf. (30), aceite por $73 \%$ dos inquiridos). Não parece haver, pois, uma correlação direta entre o comportamento sintático dos verbos e a possibilidade de omissão da preposição. Ou, dito de outra forma, o facto de os participantes aceitarem ou não a omissão da preposição selecionada por um dado verbo numa frase declarativa simples não implica que o mesmo se verifique na estrutura relativa.

A segunda das nossas questões de investigação diz respeito à natureza do elemento que introduz as relativas cortadoras. Tratar-se-á de um pronome relativo ou de um complementador? Os resultados deste estudo apontam para a última hipótese. Com efeito, os falantes não aceitam frases relativas cortadoras introduzidas por quem, quando o antecedente é humano (cf. resultados de QI2), mesmo quando consideram muito naturais frases relativas cortadoras com os mesmos verbos (e.g. falar, precisar, gostar, recordar-se, esquecer-se, lembrar-se),

\footnotetext{
${ }^{12}$ Exceto com o verbo agradar, que é aceite sem preposição por grande parte dos falantes quando ocorre na frase declarativa simples (cf. supra (30)), mas não o é na frase relativa (cf. supra (38)), e nos casos em que a relativa cortadora é introduzida por quem.
} 
mas introduzidas pelo relativizador que. Estes dados validam a proposta que tem sido apresentada na literatura com base na análise de corpora e na intuição dos investigadores, de acordo com a qual o elemento que introduz as frases relativas cortadoras é um complementador.

Os dados recolhidos para dar resposta à nossa terceira questão de investigação (QI3) mostram uma tendência para a aceitação de frases relativas cortadoras com verbos com uma frequência absoluta comparável a gostar de, precisar de, falar de e necessitar de, habitualmente não considerados na literatura, e que selecionam uma preposição gramaticalizada de ou $a$, tais como recordar-se, esquecer-se, lembrar-se, assistir. No entanto, os resultados não são homogéneos, pois com chegar a os falantes não aceitaram a omissão da preposição, talvez por esta ter um peso semântico expressivo, de alvo, e também por este se tratar de um verbo inacusativo.

Por último, com a quarta questão de investigação, verificámos que há omissão da preposição de em frases relativas em que ocorrem outros verbos que a selecionam, tais como esquecer-se de, lembrar-se de e recordarse de. Também identificámos relativas cortadoras com o verbo assistir, que seleciona a preposição $a$, de reduzida saliência fonológica; no entanto, o mesmo não sucede com agradar $a$, possivelmente devido ao facto de este verbo só admitir um objeto humano, que é o antecedente da frase relativa, e os falantes terem rejeitado consistentemente frases relativas introduzidas por quem. Além disso, a preposição atribui o Caso dativo com agradar e o caso oblíquo com assistir, contrariando a tendência identificada por Aßmann e Rinke (2017) para a maior frequência de relativas cortadoras com o Caso dativo (cf. secção 3.1.). Finalmente, verificámos que o apagamento da preposição foi aceite por uma parte expressiva dos falantes inquiridos, mesmo nos casos em que esta é dotada de maior conteúdo semântico, com as combinatórias participar em e concordar com.

Recorde-se que os três objetivos que motivaram este estudo empírico foram: (1) propor uma derivação sintática mais adequada para as relativas cortadoras em PE; (2) identificar a natureza do constituinte nulo (variável ou pro) e a sua categoria sintática (DP ou PP); (3) identificar constantes que nos permitissem predizer novos contextos para a ocorrência de cortadoras, observando, nomeadamente, a relação entre as frases relativas cortadoras e a frequência absoluta dos verbos com que ocorrem ou a escassa robustez acústica e/ou semântica da preposição.

Para o terceiro, não conseguimos recolher dados conclusivos. De facto, se há evidência de outros contextos de omissão da preposição em estruturas relativas com verbos de elevada frequência absoluta (tais como esquecer-se de, lembrar-se de, recordar-se de), como vimos, chegar a não apresenta o mesmo comportamento. Por outro lado, o fraco peso acústico e/ou semântico da preposição também não é determinante, pois observámos casos em que a preposição tem um peso acústico e valor semântico comparáveis mas com resultados opostos, tais como agradar a e assistir a. A presença de um antecedente [-humano] parece favorecer a ocorrência de cortadoras quando a preposição é pouco robusta fonológica ou semanticamente, o que faz sentido, dada a natureza neutra do elemento relativizador que as introduz.

A observação dos exemplos que foram considerados mais naturais pelos participantes no nosso estudo leva-nos a avançar uma hipótese inicialmente não considerada e que se prende com a identificação de uma constante, nos casos em que ocorrem relativas cortadoras. Esta proposta parte da observação do valor semântico dos argumentos nas situações representadas nas frases, nomeadamente, dos seus papéis temáticos (excluindo os exemplos encabeçados por quem, que, como vimos, são consistentemente rejeitados pelos participantes). 
Considerando apenas os itens testados, observamos que os participantes tendem a aceitar frases cortadoras nos casos em que o papel temático do sujeito da frase relativa é o de experienciador ou agente (com algumas exceções, como detalharemos adiante), não avaliando da mesma forma as frases relativas cortadoras quando o sujeito da frase encaixada tem o papel temático de tema (cf. tabela 5, onde se repetem as frases cortadoras introduzidas pelo relativizador que já referidas anteriormente, para facilidade de leitura).

\begin{tabular}{|c|c|c|c|c|}
\hline \multirow[t]{2}{*}{ Verbo } & \multirow[t]{2}{*}{ Item testado } & \multicolumn{3}{|c|}{$\begin{array}{l}\text { Papel temático do suj eito da relativa } \\
\text { (\% de aceitação) }\end{array}$} \\
\hline & & Experienciador & Agente & Tema \\
\hline lembrar-se (de) & (58) *A história que o médico se lembrou é engraçada. & $69,6 \%$ & & \\
\hline esquecer-se (de) & (59) * O livro que o Gonçalo se esqueceu era essencial para a aula. & $75,9 \%$ & & \\
\hline recordar-se (de) & (60) * A festa que a avó se recordou foi marcante para todos & $58,2 \%$ & & \\
\hline gostar (de) & (61) *Os livros que o Vasco gosta são interessantes & $83,5 \%$ & & \\
\hline assistir (a) & (62) * Os ensaios que os al unos assistiram correram muito bem. & $67,9 \%$ & & \\
\hline concordar (com) & (63) *A lei que os políticos concordaram é polémica. & $53,2 \%$ & & \\
\hline precisar (de) & (64) *A mochila que o Francisco precisa é cara! & $91,1 \%$ & & \\
\hline precisar (de) & (65) * Os apoios que os bolseiros precisam não foram concedidos pelo governo. & $86,1 \%$ & & \\
\hline falar (de) & (66) *Os temas que o Gonçalo falou ao jantar são interessantes. & & $65,8 \%$ & \\
\hline chamar algo (a) algo & (67) *A instituição que o António chamou antiquada fechou as portas. & & $58,2 \%$ & \\
\hline participar (em) & (68) *O espetáculo que a cantora participou realizou-œe no Campo Pequeno. & & $54,4 \%$ & \\
\hline viver $(\mathrm{em})$ & (69) * O apartamento que os amigos vivem é espaçoso. & & & $19,0 \%$ \\
\hline chegar (a) & (70) * O jardim que o Pedro chegou é bonito. & & & $13,9 \%$ \\
\hline concordar (com) & (71) * O professor que os alunos concordaram é antipático. & $10,1 \%$ & & \\
\hline dialogar (com) & (72) *O professor que os alunos dialogaram é atencioso. & $16,5 \%$ & & \\
\hline
\end{tabular}

Tabela 5 - Taxas de aceitação das relativas cortadoras introduzidas por que, considerando o papel temático do sujeito da frase encaixada

As relativas cortadoras são avaliadas positivamente quando o objeto relativizado é o complemento do verbo precisar (cf. (64) e (65)) e do verbo psicológico factivo gostar (cf. (61)), validando o que é descrito na literatura para estes verbos, mas também com verbos psicológicos não emotivos (tais como lembrar-se, esquecer-se, recordar-se, cf. (58), (59) e (60)), com um verbo de perceção sensorial (assistir, cf. (62)) e com um verbo epistémico (concordar, cf. (63)) (na sua aceção não simétrica) ${ }^{13}$. Todos eles têm em comum o facto de denotarem estados mentais e de, na sua grelha argumental, selecionarem um argumento externo com o papel temático de experienciador - afetivo com gostar, percetual com assistir, cognitivo com concordar (cf. Raposo,

\footnotetext{
${ }^{13} \mathrm{O}$ verbo concordar foi testado em dois itens com estruturas diferentes. Na frase (71), há uma relação de simetria semântica entre o argumento externo e o argumento interno, e a preposição com tem um valor comitativo. Esta estrutura é idêntica à testada com o verbo dialogar (cf. 72). Concordar é um dos exemplos de simetria apresentados em Baptista (2004:354), entendendo-se, por simetria "as propriedades sintácticas e semânticas de certas construções, em que dois constituintes, de igual natureza distribucional, estabelecem com o elemento predicativo uma idêntica relação semântica, que implica necessariamente uma reciprocidade e de que resulta poderem trocar de posições ou aparecerem coordenados numa dada posição sintáctica sem que, apesar disso, o significado global da frase se altere.” (Baptista, 2004:354). Nestes dois casos, é possível a ocorrência de apenas um argumento externo sob requisito de pluralidade, conforme exemplificado em (i) e (ii):

(i) O professor e os alunos concordaram

(ii) O professor e os alunos dialogaram.

No exemplo (63), em que concordar não apresenta uma relação simétrica, tal não é possível:

(iii) $\quad *$ Os políticos e a lei concordaram.

Embora as frases (63) e (70) testem o mesmo verbo, as estruturas sintáticas destas construções não são idênticas, pois em (71) há uma simetria sintático-semântica entre o argumento externo e o argumento interno que não se verifica em (63). Assim, a simetria semântica das frases (71) e (72) sugere que o argumento interno (relativizado) e o argumento externo (sujeito da relativa) têm o mesmo papel temático, possivelmente de experienciador.

Em (63), o argumento interno relativizado é o tema (a lei) e o argumento externo o experienciador (os políticos). É possível que as relativas cortadoras sejam rejeitadas pelos falantes nas construções de alternância de (71) e (72) devido à inexistência de uma relação hierárquica entre os seus papéis temáticos. No entanto, esta linha de investigação precisa de ser explorada e fundamentada com testes adicionais.
} 
2013:378) - que desempenha a função de sujeito na frase relativa encaixada. Adicionalmente, todos selecionam um objeto com o papel temático de tema/estímulo, que é relativizado:

(73) lembrar-se, esquecer-se, recordar-se, gostar, assistir, concordar (não simétrico), precisar

experienciador, <tema/estímulo>

Quando o verbo seleciona um argumento externo com o papel temático de agente (que é o sujeito da encaixada) e um argumento interno alvo (cf. (74)) ou tema (cf. (75)), as frases foram consideradas muito naturais por mais de 50\% dos participantes, com os verbos participar (cf. (68)) e chamar (cf. (67)), ultrapassando os $60 \%$ com falar (cf. (66)).

(74) chamar

agente, $<$ tema, alvo $>$

(75) participar, falar

agente, $<$ tema $>$

Interessante é o contraste com os casos em que a grelha argumental do verbo apresenta um sujeito tema (o sujeito da frase relativa) e um complemento locativo e/ou alvo (o elemento relativizado) (cf. (76) e (77)), como com os verbos viver e chegar (cf. (69) e (70)). Neste caso, os falantes não aceitam o corte da preposição.

(76) viver

tema, $<$ locativo $>$

(77) chegar

tema, $<$ alvo $>$

Embora não haja consenso quanto à ordem exata apresentada numa hierarquia de papéis temáticos, as propostas existentes na literatura são unânimes ao considerar que os papéis temáticos de agente e experienciador ocupam uma posição hierárquica elevada e que os papéis temáticos de tema e/ou locativo apresentam uma posição mais baixa. Raposo (2013: 389) propõe a seguinte hierarquia para o português:

(78) agente $>$ causa $>$ experienciador $>$ paciente/tema $>$ locativo/estímulo

No entanto, Grimshaw (1990) (apud Raposo, 2013:434) apresenta os papéis de locativo e de tema na ordem inversa, situando-os, em todo o caso, abaixo de 'agente' e de 'experienciador':

(79) agente $>$ experienciador $>$ origem/alvo/locativo $>$ tema

Haverá alguma relação entre o corte da preposição e os papéis temáticos atribuídos pelo verbo da frase encaixada? Nos dados analisados, nos casos em que o sujeito da relativa, argumento externo do verbo testado, tem um papel temático que ocupa uma posição mais alta na hierarquia (de agente/experienciador), diferente do papel temático do argumento interno, como em (73), (74) e (75), as cortadoras apresentam níveis mais altos de aceitação.

Todavia, não esqueçamos que, nas construções de alternância com os verbos simétricos concordar e dialogar (cf. (71) e (72)), as cortadoras foram rejeitadas, talvez por o argumento externo do verbo, sujeito da relativa, e o seu argumento interno, elemento relativizado, apresentarem as mesmas propriedades sintáticas e 
semânticas e papéis temáticos idênticos ${ }^{14}$ (cf. (80)), mas possivelmente também devido ao facto de o antecedente da relativa ser [+humano].

$$
\begin{aligned}
& \text { (80) concordar (recíproco), dialogar } \\
& \text { experienciador, <experienciador> }
\end{aligned}
$$

O contraste nos resultados obtidos com o verbo concordar (cf. (63) vs. (71)) parece indicar que a natureza semântica do complemento também influencia a aceitação do corte da preposição, privilegiando-se os contextos em que o antecedente é [-humano] (como em (63)). No entanto, o facto de este verbo apresentar propriedades sintático-semânticas distintas nas duas frases testadas (cf. nota de rodapé 13) faz com que este não seja o exemplo ideal para extrair conclusões a este respeito. Dado que os itens com antecedentes humanos e a estratégia cortadora testados no presente estudo apresentam sobretudo relativas introduzidas por quem, pelas razões anteriormente referidas, não é possível verificar se este contraste entre (63) e (71) se deve às propriedades específicas do verbo concordar ou à natureza [+/-] humana do antecedente da relativa. Assim, em trabalhos futuros, será interessante verificar se os mesmos verbos que aqui se mostram permeáveis à ocorrência de cortadoras têm níveis de aceitação idênticos com antecedentes [+hum] introduzidos por que.

Não obstante toda a reflexão anterior sobre a relação entre os papéis temáticos dos verbos testados e a aceitação de frases relativas cortadoras, os papéis temáticos dos argumentos que constituem as frases testadas não foram uma variável sistematicamente controlada neste estudo, dado tratar-se de uma hipótese levantada na sequência da observação dos dados que dele decorrem. Em investigação futura, valerá também a pena controlar esta variável e levantar hipóteses que justifiquem uma eventual relação entre a atribuição dos papéis temáticos e a aceitação da omissão da preposição. Ou, dito de outra forma, merecerá a pena procurar regularidades semânticas nos predicadores mais atreitos à ocorrência de relativas cortadoras, pois estas poderão ser importantes para predizer contextos futuros de ocorrência destas estruturas.

Para concluir, as relativas cortadoras não parecem depender apenas de um fator, mas de uma combinação de aspetos: preposições pouco expressivas, do ponto de vista fonológico e semântico, associadas a um antecedente desprovido de traços humanos parecem ser um contexto favorável para estas estruturas. Os dados aqui analisados sugerem que as propriedades semânticas dos argumentos que integram as relativas cortadoras, nomeadamente os seus papéis temáticos, também interferem, apontando para uma tendência de aceitação deste tipo de estruturas nos casos em que o papel temático do argumento externo do verbo da encaixada ocupa uma posição mais alta na hierarquia. Há ainda variáveis extralinguísticas que aqui não foram consideradas, tais como o contexto mais ou menos formal da sua ocorrência e a influência da escolarização, que poderão propiciar a ocorrência destas estruturas.

Os outros dois objetivos deste trabalho são de natureza teórica: a proposta de derivação sintática e a natureza e categoria do constituinte nulo. Procurámos suportar as nossas propostas nos dados empíricos que recolhemos.

Como se sabe, as frases relativas canónicas foram alvo de muitas análises nas últimas décadas, nomeadamente de elevação (Kayne 1994, Bianchi 1999, entre outros) e matching (Chomsky, 1965; Sauerland, 1998, entre outros). A hipótese que aqui apresentamos atualiza as propostas de elevação de Bianchi (1999) e Kayne (1994) para as relativas canónicas.

Quando a preposição é omitida em todos os contextos, cremos que a estrutura sintática é idêntica à proposta para as relativas de OD por Brito (1991), pois já não entra na numeração (pensando numa grelha

\footnotetext{
${ }^{14}$ Embora aqui consideremos que o papel temático associado aos verbos concordar e discordar é o de experienciador, em Mateus et al. (2003:199) o argumento interno de um verbo aparentado, conversar, aparece classificado como 'alvo'. Admitimos, pois, a hipótese de o argumento externo e de o argumento interno de concordar e discordar serem 'alvo', mantendo a mesma relação semântica com o predicador.
} 
argumental como a apresentada em (57b.). Assim, na linha de Brito (1991) para as relativas de OD, assume-se que o NP antecedente da relativa é gerado na posição de objeto, sendo encabeçado por um D nulo (seguindo Bianchi, 1999), que é portador de um traço interpretável relativo [ $i$ REL] e de um traço interpretável determinante $[i$ Det]. O complementador que é inserido na posição de núcleo de $\mathrm{CP}$, ostentando o traço não interpretável relativo [ $u$ Rel] e um traço não interpretável [ $u$ Det], que o leva a sondar por um elemento contra o qual possa verificar estes traços. Consequentemente, o DP (com D nulo) move-se para a posição de Spec, CP, de modo a estabelecer uma relação de Agree com o complementador, tal como representado na figura 1.

(81) O livro que a Maria precisa.

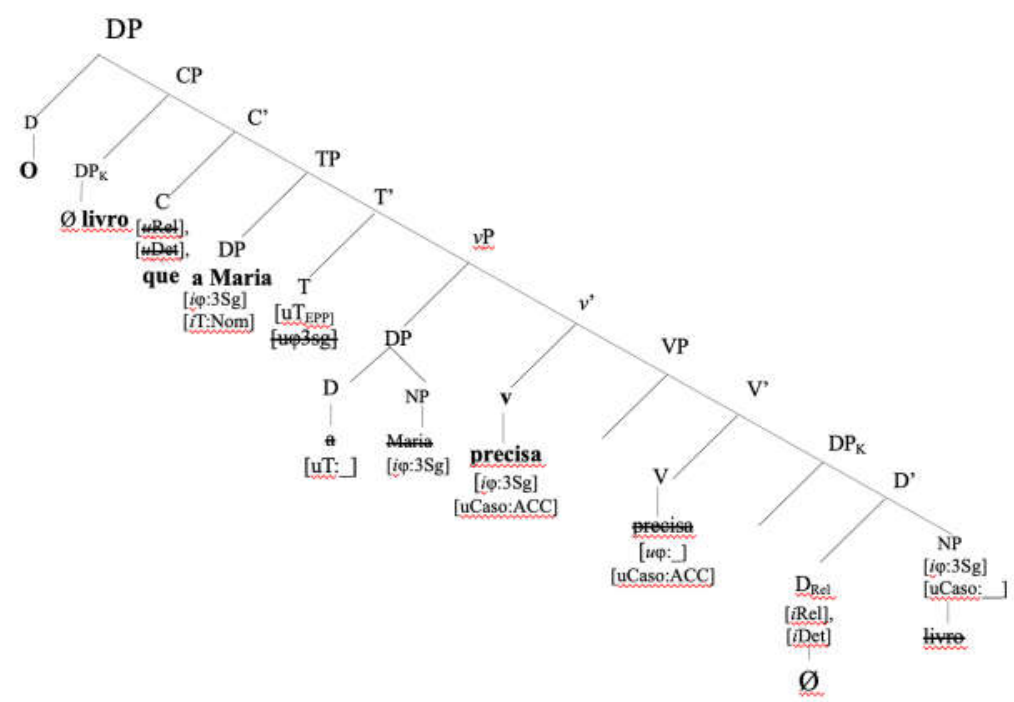

Figura 1 - Proposta de derivação para uma frase relativa cortadora quando a preposição não integra a grelha argumental do verbo

Nos casos em que estamos perante verdadeiras cortadoras, ou seja, naqueles em que a grelha argumental do V não sofreu alterações (cf. (57a.)), sugerimos uma derivação com movimento do DP antecedente, tal como a apresentada para as relativas de OD e a proposta na Figura 1 para as relativas cortadoras que resultam da grelha argumental (57b.).

No entanto, neste caso, assume-se que há uma preposição na numeração, a qual irá encabeçar o PP complemento do verbo. Este PP é gerado na posição de objeto, tendo um DP com um D nulo como complemento (Bianchi, 1999), que é portador de um traço interpretável relativo [ $i$ REL] e de um traço interpretável determinante $[i$ Det $]$. O complementador que é inserido na posição de núcleo de $\mathrm{CP}$, ostentando os traços não interpretáveis relativo $[u \mathrm{Rel}]$ e determinante $[u \mathrm{Det}]$, que o levam a sondar por um elemento contra o qual possa verificar estes traços. O que acontece à preposição que é cortada? Para esta questão, ainda não há respostas conclusivas.

Se as razões para a ausência da preposição forem de ordem sintático-semântica (nomeadamente se se relacionarem com questões na grelha argumental dos verbos que envolvam os seus papéis temáticos), a preposição não fará parte da numeração e a derivação será idêntica à apresentada na figura 1 .

Se não forem identificadas razões de ordem sintático-semântica que motivem a queda da preposição com estes verbos especificamente em frases relativas, dado que não há evidências de que o objeto movido seja um PP (cf. QI2), então terá de se admitir que a preposição é apagada na componente pós-sintática (na componente 
fonológica), não chegando a mover-se, eventualmente devido à inexistência da estratégia de abandono de preposição em português (tal como proposto, por exemplo, para o crioulo de Cabo-Verde por Alexandre, 2012: 121-122).

Já sem Prep, o DP (com D nulo) move-se para a posição de Spec, CP, de modo a estabelecer uma relação de Agree com o complementador. O movimento do DP baseia-se nos testes clássicos apresentados no início deste trabalho, nomeadamente na sensibilidade das estruturas cortadoras a efeitos de cruzamento forte e a ilhas fortes, e no facto de estas legitimarem lacunas parasitas (cf. secção 5, QI1). Esta derivação é apresentada na figura 2.

(82) O rapaz que a Maria gosta.

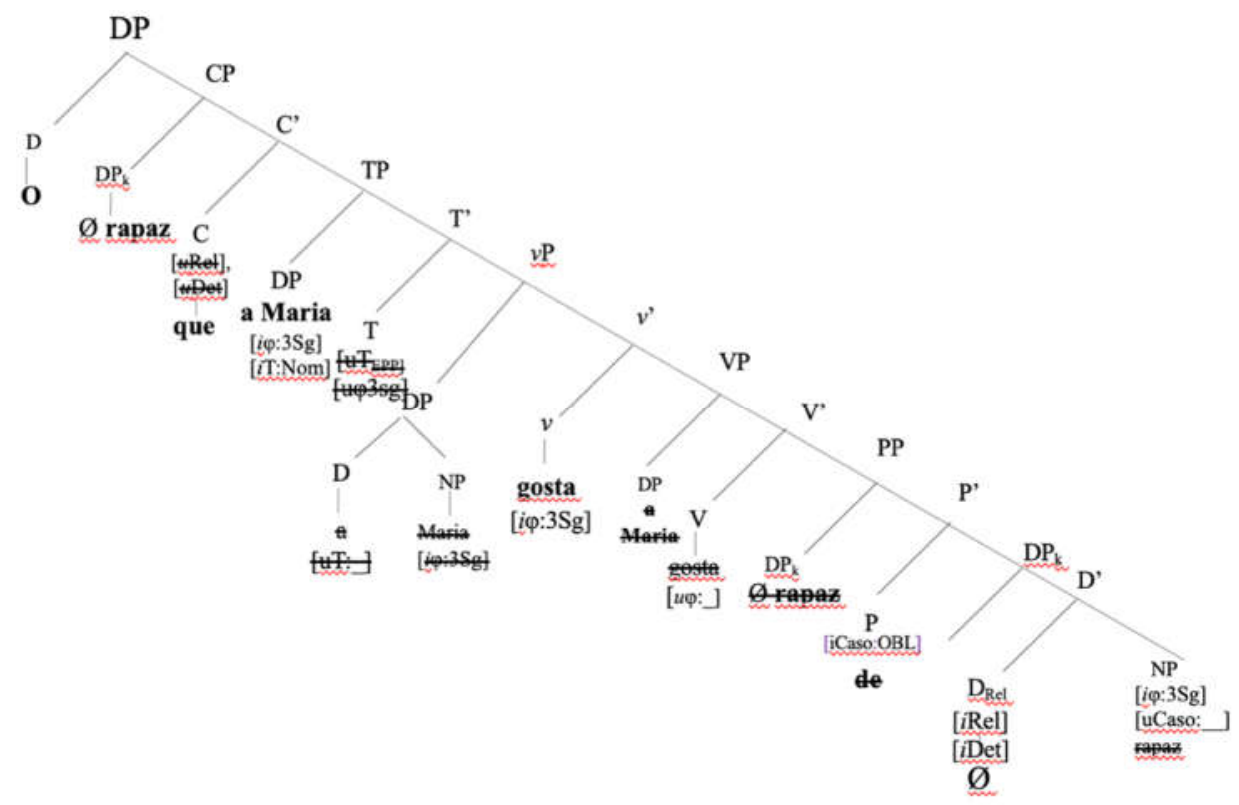

Figura 2 -Proposta de derivação de uma frase relativa cortadora

Por último, considerando os testes efetuados (lacunas parasitas, cruzamento forte e ilhas), a cópia nula apresenta propriedades de variável.

\section{Conclusões}

As relativas cortadoras em PE não parecem estar totalmente relacionadas com alterações nas propriedades de seleção categorial dos verbos testados, confirmando-se o já proposto anteriormente (e.g., Brito, 1995).

Assim, o mesmo output pode ter duas gramáticas diferentes subjacentes, tratando-se de duas gramáticas em competição. Para os falantes que aceitam declarativas sem Prep com os verbos precisar, necessitar, falar e agradar, estas frases serão relativas de OD (com a derivação correspondente). Para os falantes que não aceitam declarativas sem preposição, serão relativas cortadoras também com estes verbos. 
As relativas cortadoras com os verbos gostar, assistir, recordar-se, esquecer-se, lembrar-se parecem ser de facto "verdadeiras" cortadoras, i.e., casos em que a preposição é apagada na componente fonológica. O mesmo acontece com outros verbos em que a preposição tem mais peso semântico e fonológico (concordar com, participar em).

Assumimos que um indicador do movimento da preposição seria a possibilidade de ocorrência do pronome relativo. Os dados empíricos recolhidos (nomeadamente, a generalizada não aceitação do pronome relativo quem a introduzir frases relativas cortadoras) afastam a hipótese de as cortadoras terem uma derivação semelhante à das relativas com pied-piping, i.e., com movimento da preposição.

Os dados apontam ainda para algumas regularidades de natureza semântica com os verbos em que as cortadoras são mais frequentes, nomeadamente no tipo de papel temático do argumento externo do verbo, sujeito da relativa, e nas propriedades semânticas do seu argumento interno, objeto relativizado, que merecem ser aprofundadas em trabalhos futuros.

Tendo em conta os dados obtidos, as cortadoras parecem ser também evidência de um processo de simplificação do sistema dos pronomes relativos, visível no recurso à forma que mesmo em contextos onde seriam esperadas formas mais complexas (cf. Alexandre e Hagemeijer, 2011; Brito, 1995). Possivelmente, o facto de o antecedente da relativa ter um traço [- humano] contribui para o apagamento da preposição, uma vez que propicia a ocorrência do relativizador que, desprovido de traços de humanidade, em detrimento de quem, dotado do traço [+ humano].

Por fim, respondendo à questão que intitula este trabalho, cremos que a derivação implica primeiro movimento e depois corte: Mover DP, Abandonar Prep > Cortar Prep em PF. Há movimento do DP antecedente, mas sem arrastamento da preposição. Uma vez que o abandono de preposição não está disponível em PE, a preposição será depois apagada na componente fonológica.

\section{Referências:}

Alexandre, N. (2000) A Estratégia Resumptiva em Relativas Restritivas do Português Europeu. Dissertação de Mestrado, Universidade de Lisboa.

Alexandre, N. (2012) The Defective Copy Theory of Movement. Amsterdam/Philadelphia: John Benjamins Publishing Company.

Alexandre, N., Gonçalves, R., e Hagemeijer, T. (2011) A Formação de Frases Relativas de PP No Português Oral de Cabo Verde e de São Tomé. In A. B. e I. Falé (Eds.). Textos Seleccionados do XXVI Encontro Nacional da APL 2010, pp. 17-34.

Alexandre, N. e Hagemeijer, T. (2013) Estratégias de relativização de PPs no mundo luso-atlântico: crioulos de base lexical portuguesa e variedades do português. In D. Moura e M. Sibaldo (eds.). Para a História do Português Brasileiro-Volume III: Sintaxe Comparativa entre o Português Brasileiro e Língua Crioulas de Base Lexical Portuguesa, Tomo IV, Maceió: EDUFAL, pp. 49-71.

Arim, E., Ramilo, M. C., e Freitas, T. (2004) Estratégias de Relativização Nos Meios de Comunicação Social Portugueses. In T. Freitas e A. Mendes (Eds.). Actas do XIX Encontro Nacional da APL, pp. 279-88.

Aßmann, E. e Rinke, E. (2017) Relative Clauses in a Spoken Corpus of European Portuguese: Identifying the Factors Determining Their Variation. Linguística: Revista de Estudos Linguísticos da Universidade do Porto (12), pp. 9-39.

Baptista, J. (2004) Construções simétricas: argumentos e complementos. In Figueiredo, O., G. Rio-Torto \& F. Silva (orgs.). Volume de homenagem ao Prof. Mário Vilela. Porto: Campo das Letras, pp. 353-367.

Bianchi, V. (1999) Consequences of Antisymmetry. Headed Relative Clauses. Berlim/ Nova Iorque: Mouton de Gruyter. 
Brito, A. M. (1991) A Sintaxe das Orações Relativas em Português. Lisboa: INIC.

Brito, A. M. (1995) As orações relativas restritivas nas variantes culta e oral em quatro línguas românicas, com especial incidência em Português. Lusorama. Revista de Estudos sobre os Países de Língua Portuguesa, pp. $71-81$.

Brito, A. M. e Duarte, I. (2003a) Orações Relativas e Construções Aparentadas. In M.H.M. Mateus et al. Gramática da Língua Portuguesa. Lisboa: Editorial Caminho, pp. 653-85.

Brito, A. M. e Duarte, I. (2003b) Predicação e classes de predicadores verbais. In M.H.M. Mateus et al. Gramática da Língua Portuguesa. Lisboa: Editorial Caminho, pp. 179-203.

Chomsky, N. (1965). Aspects of the Theory of Syntax. Vol. 11. MIT Press.

Duarte, I. (2003) Verbos com propriedades de seleção não homogéneas. In M.H.M. Mateus et al. Gramática da Língua Portuguesa. Lisboa: Editorial Caminho, pp. 636-640.

Duarte, I. (2013) Passeando Pela Língua Portuguesa. II Congresso Internacional da Faculdade de Letras da Universidade Federal do Rio de Janeiro, pp. 1-25.

Gonçalves, R. (2010) Propriedades de subcategorização verbal no português de São Tomé. Dissertação de Mestrado, Universidade de Lisboa.

Grimshaw, J. (1990) Argument Structure. Cambridge/ Massachusetts: The MIT Press.

Kayne, R. S. (1994) The Antisymmetry of Syntax. Cambridge/ Massachusetts: The MIT Press.

Kenedy, E. (2007) A Antinaturalidade do Pied-piping em Orações Relativas. Dissertação de Doutoramento. UFRJ.

Klein, E. C. (1993) Toward Second Language Acquisition. A Study of Null-Prep. Dordrecht: Springer Netherlands.

Luft, C. P. (1987) Dicionário prático de regência verbal. Ática.

Peres, J. A. e Móia, T. (1995) Áreas Críticas da Língua Portuguesa. Lisboa: Editorial Caminho.

Raposo, E. P. (2013) Organização semântica da frase e Estrutura Argumental. In E. P. Raposo et al. (eds.). Gramática do Português. Lisboa: Fundação Calouste Gulbenkian, pp. 369-394.

Rinke, E. e Aßmann, E. (2017) The Syntax of Relative Clauses in European Portuguese. Extending the Determiner Hypothesis of Relativizers to Relative que. Journal of Portuguese Linguistics, 16(1), pp. 1-26.

Santos, C. S. (2014) Relativas Cortadoras No Português Europeu Falado: Interação Com as Variáveis Sociais. Dissertação de Mestrado, Universidade do Minho.

Sauerland, U. (1998). The Meaning of Chains. The MIT Press.

Tarallo, F. (1985) The Filling of the Gap: Pro-Drop Rules in Brazilian Portuguese. In L. King and C. Maley (Eds.). Selected Papers from the XIIIth Linguistic Symposium on Romance Languages). Amsterdão: John Benjamins, pp. 355-75.

Veloso, R. (2007) Orações Relativas em Contextos Apresentativos: Dados de Um Corpus Oral. Comemorações Dos 75 Anos do CLUL.

Veloso, R. (2013) Subordinação Relativa. In E. Paiva Raposo et al. (eds.). Gramática do Português. Lisboa: Fundação Calouste Gulbenkian, pp. 2061-2136. 